The First Stone and the Last Tasmanian: The Colonial Correspondence of Edward Burnett Tylor and Henry Ling Roth.

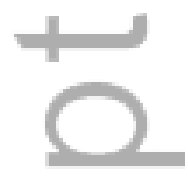

=

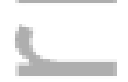

Rebe Taylor

University of Melbourne

ABSTRACT

Between 1890 and 1905, Edward Burnett Tylor and Henry Ling Roth extended and formalised two ideas that were intricately connected and deeply influential to the development of nineteenth century anthropology: that the Tasmanian Aboriginal people represented the earliest phase of cultural evolution and that they were extinct. This paper offers a detailed archival exploration of the correspondence between 18911905 that informed those ideas. It finds that Tylor and Roth not only received abstracted facts and artefacts from their colonial contacts; they were directed and inspired by an emergent Australian scholarship that sought to propose and urge new disciplinary directions. This paper reveals not only the importance of Tasmanian Aboriginal people to the history of science, but the role that scientific ideas have shaped Australian social memory and national identity.

Keywords: Tasmania, Aborigines, Tylor, Ling Roth, Australia

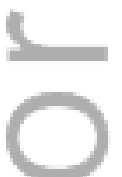

\title{
INTRODUCTION
}

If Aboriginal Australians were essential subjects in the development of the theories of evolutionism because of their 'primitivism', Tasmanian Aboriginal people held a special significance. They were deemed to be one of the most isolated and unique races in the world, and also the most primitive, 'lower' even than the Aboriginal peoples of mainland Australia. Tasmanian Aboriginal material culture was believed by early theorists to equate to the recently discovered European 'Stone Age'. Thus they represented a 'survival' from a very distant past. They were also the only

This is the author manuscript accepted for publication and has undergone full peer review but has not been through the copyediting, typesetting, pagination and proofreading process, which may lead to differences between this version and the Version of Record. Please cite this article as doi: 10.1002/ocea.5145 
'race' colonised by the British to become 'extinct'. From the 1830 , when the colonial frontier Black War was ending, the Tasmanian Aboriginal peoples' extinction was deemed inevitable; it was declared final with the passing of Truganini in 1876, as the supposed last 'full blood' of her 'race'. The combined discourses of the 'extreme primitivism' and 'extinction' of the Tasmanians came to demonstrate the progressive laws of human evolutionary theory. Charles Darwin observed in 1871 that the Tasmanians' demise was a 'natural' consequence of 'when civilised nations come into contact with barbarians' (Darwin 1871: 238). This logic and justification for colonial conquest became, therefore, intrinsic to the shaping of British racial superiority. Historian Tom Lawson reflects that the supposed extinction of the Tasmanian Aboriginal people was not merely an 'important part of an identity in which Britain was imagined to be at the apex of human progress', it 'relied' upon it. Even the widely voiced regret over their passing was often 'tinged with pride' over the demonstrated 'might' of the Empire (Lawson 2014: 162, 171). This regret reemerged in late twentieth century Australia as a collective sense of national shame. But the reiteration of extinction offered contrition without recompense and denied a contemporary Tasmanian Aboriginal community recognition of their existence and rights.

This article offers the first detailed historical exploration of the development of the ideas of extreme primitivism and the extinction of Tasmanian Aboriginal people. It identifies two major exponents: Edward Burnett Tylor, the founder of British anthropology, who originated the theory of the Tasmanian Aboriginal peoples' 'extreme primitivism' based largely upon the study of just one stone tool, the famous 'Taunton Scraper' in about 1860; and Henry Ling Roth, a gentleman anthropologist and English businessman, who sought to verify which Tasmanian Aboriginal person was the last 'fullblood'. Their projects were founded on gross misjudgments and misuse of Tasmanian Aboriginal peoples' culture and bodies but both men were regarded as the leading authorities on the topic. Tylor's 1894 paper, 'On The Tasmanians as Representatives of Paleolithic Man' was widely referenced and seen as fundamentally influential to the understandings of human origins and cultural development. Roth's The Aborigines of Tasmania (1890) was the first anthropological book on the subject. The second edition, published in 1899 , 
remained the most referenced text on the subject, reiterating the 'fact' of extinction, until the mid-196os.

This article reveals how Tylor and Roth's authority relied heavily upon the knowledge and guidance offered to them by informants living in Tasmania: keen amateur scholars and collectors, among them published writers with expert knowledge of the Aboriginal history and collections. An examination of this extensive correspondence also brings into question the seeming collusive logic of Tylor's theory of 'extreme primitivism' and Roth's confirmation of extinction. While they accepted each other's premises, Tylor's goal to discover the representative beginning of cultural evolution, and Roth's first imperative to verify who was the 'last' Tasmanian, were distinct ambitions with different methodologies and requirements.

This archival exploration offers a second realisation: Roth and Tylor's correspondence with settler Tasmanians does not model a classical split between colony and metropole. It was carried out on the eve of Federation in 1901, and in Tylor's case, continued for some years after. The letters from Tasmania reveal an emergent Australian scholarship that was finding its own direction, capability and recognised centres of expertise. The writers understood their role as directing and influencing the British scholars whom they assumed knew less about 'their' local Aborigines.

These realisations and their implications are explored in this article across two major parts and an epilogue. 'The First Stone' examines Tylor's interest in the Tasmanian Aboriginal people from 1860 to 1905. It begins with his famous encounter with the 'Taunton Scraper' in 1860 (Griffiths 1996: 53; Murray 1992; Mulvaney 1990: 45; McNiven and Russell 2005: 64-66), and then enriches these accounts with further detail, including the association between Tylor and Roth. Helen Macdonald's astute observation that Tylor's 1894 paper intersected and extended the significant and longstanding debate between the theories of monogeny and polygeny is extended to reveal how Tylor's work inspired the worldwide collection and study of Tasmanian stone artefacts as a way to understand human cultural history. The article also offers the first exploration of an extensive correspondence between Tylor and a local collector, Joseph Paxton Moir between 1898-1906. Moir challenged Tylor's theory of the Tasmanians as early 'Palaeolithic', arguing their stone culture showed diversity 
and skill, an idea that foreshadowed how leading scholars interpreted Tasmanian stone culture in the twentieth century (Balfour 1925; Mulvaney 1990).

The paper's second section, 'The Last Tasmanian', explores Roth's correspondence with Tasmanian local scholars between 1891 and 1899, foremost with Hobart-born barrister and local historian, James Backhouse Walker. Roth instigated the correspondence after reading that Mrs Fanny Smith (nee Cochrane) was a 'full-blood' Tasmanian Aboriginal (Barnard 1889). The request to verify this claim inspired an eight-year correspondence with Walker that resulted in a much-altered second edition of The Aborigines of Tasmania in 1899. This exchange has been explored in some detail (Felton 2012 and McDougall 2007), but this paper offers a more expansive account that places it in context with coeval work of Tylor and Moir and also includes Roth's correspondence with Tasmanian photographer, J. W. Beattie.

Further, this paper brings to light how Walker sat at the centre of what Moir described as a 'circle or clique' of scholars who dominated the study of Tasmanian Aboriginal history and culture. ${ }^{1}$ Hobart was their own metropole from which they gathered and filtered anthropological ideas they collected from around the colony, then state, largely through their own correspondence, and then disseminated it onto Britain. The Hobart 'circle' operated in parallel to what Tom Griffiths identifies as Victoria's 'stone circle' of amateur anthropologists clustered at this time around Melbourne's Professor Baldwin Spencer who dominated the interpretation and collection of Aboriginal artefacts and culture in that colony. While Spencer formed his ideas in 'dialogue with European theorists', his circle also 'turned their backs on them'. They were openly 'suspicious' of 'armchair theorists', promoting fieldwork and collecting, as the only way to understand and interpret Aboriginal culture (Griffiths 1996: 67, 70, 78).

While Walker and his circle rarely left Hobart, and while they also deferred many of their ideas and findings to Britain, like the Victorian circle, the Hobart scholars were conservative in their interpretations. Both groups accepted that the Aborigines represented a 'low' level of human cultural evolution, with little history of change, and as such their findings supported the persistence of evolutionary understandings of Aboriginal cultures.

It was the scholars who sat at the margins of the Hobart and Melbourne circles whose ideas challenged most vigorously those of the metropole, and in turn 
foreshadowed some of the key developments in Australian anthropology and archaeology. This is evident in Moir's unusual ideas about the variation and skill of Tasmanian stonework. An important corresponding example found in the work of anthropologist, magistrate and co-author of Kamilaroi and Kurnai Alfred W. Howitt. In 1898, Howitt contended that the Tasmanian Aboriginal people had reached their island by foot before rising seas at the end of the Pleistocene (around 12,00o years ago) created the Bass Strait (Griffiths 1996: 62-63). Howitt was in communication with, but not part of, Spencer's inner circle, which remained sceptical of Aboriginal antiquity well into the twentieth century. But the question of the Tasmanians' origins and possible antiquity became one of the founding debates of Australian archaeology. By 1961, under the leadership of archaeologist John Mulvaney, the question of Tasmania's antiquity was central to the discipline's wider goal to determine the depth of the continent's human occupation (Mulvaney 1990: 15).

In an epilogue this paper explains the importance of Roth's and Tylor's correspondence to understanding the ideas and discoveries of twentieth century Tasmanian archaeology. In 1965 archaeologist Rhys Jones surmised that Howitt had been right: the first Tasmanians had reached their country across a dry Bassian plain (Jones and Meehan 2000: 40). But Jones stirred controversy when he suggested that the Tasmanian Aboriginal people had suffered an isolation-induced regression and even if colonisation had never occurred that they may nonetheless have been 'doomed' to extinction. (Jones 1977: 197, 202-203). The Aboriginal and academic communities accused Jones of reiterating nineteenth-century evolutionary theory. (Bickford 1979: 14, Bowdler 1980: 335, Ryan 1985 and 2012: xix-xx). In fact Jones was a passionate anti-colonialist, and his scientific ideas were more closely connected to Howitt than to Tylor, for he had sought to realise the depth and change within Aboriginal history.

Finally, this paper concludes that to understand the difference between Jones' and Tylor's research goals it is necessary to first recognise the distinctions between Tylor's and Roth's interests in the Tasmanian Aboriginal peoples' 'primitivism' and 'extinction'. For only then does it become possible to elucidate the ways an emergent colonial scholarship did more than underpin those scholars' ideas, it also proposed and urged new disciplinary directions. 


\section{THE FIRST STONE}

In 1860 Edward Burnett Tylor was at the beginning of a career that would establish the discipline of social anthropology as a science. In that year he attended a meeting of the Somerset Archaeological Society in Taunton where Mr Thomas Dawson presented a small stone implement from Tasmania. Tylor noted how the tool was chipped roughly, but effectively, on one side creating a sharp edge for scraping (Tylor 1890: v-vi). He was struck by the tool's apparent similarity with the European artefacts found in the Somme river gravels that only months earlier had been confirmed as dating back to the last Ice Age, or Pleistocene (Sackett 2014: 1). The comparison was a revelation. As Tylor later put it: 'Man of the Lower Stone Age ceases to be a creature of philosophic inference, but becomes a reality' (Tylor 1899: ix). The European Stone Age was both remote in time, and yet an object of recent discovery. The 'Taunton Scraper', as the small Tasmanian tool came to be famously known, encapsulated the deep past for Tylor; it was as if he could hold the beginning of human culture in the palm of his hand. The single tool continued to play an inspiring role throughout Tylor's lifework, shaping fundamentally his theories of cultural evolutionism. The reverse was also true; the ways Tylor presented and interpreted the Taunton Scraper developed in accordance with his wider thinking and experience earned through researching the Tasmanian artefacts more thoroughly, and his wider studies into world cultures.

In 1862, Tylor attended the Great Exhibition in London and met Joseph Milligan, Commissioner for Tasmania, and former superintendent of the Oyster Cove Aboriginal Station, south of Hobart. Tylor asked Milligan if he thought the Taunton Scraper was typical in its manufacture. Milligan explained to him, he later quoted, that the Aborigines would 'pick up a suitable flat stone, knock off chips from one side, partly or all round the edge, and use it without more ado' (Tylor 1890: vi). So it was that in his 1865 book, Researches into the Early History of Mankind Tylor wrote that: 'the Natives of Van Diemen's Land, whose dismal history is ending in total extinction, are the lowest tribes known to ethnology' (Tylor 1964: 195). It was perhaps with Tylor's influence that in the same year British archaeologist, John Lubbock also made a comparison between the 'Van Diemener' (Tasmanian 
Aboriginal person) and the Stone Age culture, to which he gave the name the 'Paleaolithic' (Lubbock 1865: 336-337).

Tylor did not return to the subject of the Tasmanian Aboriginal culture until he wrote the Preface to Henry Ling Roth's 1890 The Aborigine of Tasmania. He explained his intense interest in the subject: while there were many extant Stone Age tribes, the Tasmanian Aboriginal people alone illuminated the earliest phase of European culture. If it seemed improbable that men of the 'Drift' (as he termed the Last Ice Age) held their axes rather than haft them, their 'ignorance' became plausible 'because it prevailed in Tasmania' (Tylor 1890: v-vii).

Tylor's interest in the Tasmanians renewed, he explored his thinking across five papers written between 1894-1900 (Tylor, 1894, 1895, 1898, 1900). The first publication, 'On The Tasmanians as Representatives of Paleolithic Man' was the most referenced. The title alone assured its impact. It reaffirmed the Tasmanians to the culture phase defined by Lubbock: the earliest phase of cultural development. Lastly, in about 1905, Tylor drafted a chapter on the cultural status of the Tasmanian Aboriginal people for his last, but unpublished book on cultural evolution. ${ }^{2}$

Since the Taunton Scraper remained almost the only Tasmanian Aboriginal stone artefact he had seen, Tylor sought to expand his collection to include a wider range of tool types. On Tylor's behalf, Roth wrote to James Backhouse Walker, in 1891: 'we, in England, are badly in want' of Tasmanian stone implements. With the exception of 'the one stone in the Taunton ... museum' and a half dozen belonging to Pitt Rivers Museum curator, Henry Balfour, 'no one at home appears to be the possessor of any.'3

Walker was slow in organising the stone artefacts, and Tylor followed up the request himself. He soon received 'a number' of stone implements from Alexander Morton, curator of the Royal Society of Tasmania's Museum, and a 'general collection' of about 150 implements from WL Williamson who ran a 'curios' shop in Browns River, near Hobart (Petch). 4 Tylor's brother-in-law, the renowned Mountaineer, Francis Fox Tuckett, consequently visited Williamson in 1895 . He found him to be 'a well-known character' who dealt with 'shells, and ancient fish-like articles with smells to match' in a 'higgledy-piggledy museum in little shed near the beach'. Williamson required exchange for the stone tools he sent to Tylor: Roman 
and English coins, shells and stamps. With the hope of a more profitable swap, he offered a skull from the Aborigines' cemetery at Oyster Cove, which Tylor declined. 5

In this Tylor was distinct. Since the mid-nineteenth century, the Tasmanians' bodies had become 'rare collectables' (MacDonald 2005: 10). As extinction seemed imminent, the collection of Tasmanian human remains became urgent and competitive. Body parts were exchanged in 'favours' and deals driven as much by the desire of possession as for any scientific intention (MacDonald 2005: 10). When Hobart hospital surgeons dissected illicitly the body of William Lanne, the so-called 'last' Tasmanian Aboriginal man in 1869, it created a public outcry. It was decreed that when Truganini died, her body should be left to rest (MacDonald 2005: 136-182, Petrow 1998: 39-40). But the Royal Society applied successfully to have her remains disinterred. For the ninety-eight years her skeleton was in the museum in Hobart, little research was ever carried out on her remains (Fforde and Hubert 2006: 83-96). There were, however, two extensive anthropological studies carried out on Tasmanian human remains in Britain in the 1870s. Tylor would later challenge these studies, and in so doing extend an older debate over human origins.

On the eve of Charles Darwin's revolutionary 1859 publication The Origin of the Species, British racial scientists had been edging towards an agreement that the cause of biological human variation was multiple and distinct origins; the theory of polygeny (Griffiths 1996: 45). Darwin's theory of transmutation, however, bolstered the counter argument for single, shared human origins; monogeny. The discovery of human antiquity also in 1859 offered the expanse of time required to successfully argue that migration and slow environmental adaption was the cause for the wide geographic distribution and physical human diversity of races.

But the debate was not resolved, and it was predictable that the Tasmanian Aboriginal people should be drawn into its centre. Their isolation and supposed physical and cultural differences lead to the assumption that they were a unique race with distinct origins (Huxley 1870: 18; Griffiths 1996: 63). The question then remained: where had the Tasmanians come from, and when?

Anatomist Joseph Barnard Davis was possessor of one of the largest private collections of human remains from across the world, including Tasmania. In 1874, Davis argued that the only logical explanation for the Tasmanians' physical and cultural differences was a distinctive biological origin; they offered an unambiguous 
case for polygeny (Davis 1874). Anatomist William Flower of the British Museum answered with reference to another large collection of skeletal material that the Tasmanians' differences and 'extreme primitivism' were the result of a slow transformation caused by a long isolation, and as such offered a clear demonstration of monogeny (Flower 1877-1879).

Tylor intersected this debate in 1894 with his paper, 'On The Tasmanians as Representatives of Paleolithic Man'.Tylor's paper was a more precise rendering of his ideas outlined in Roth's 1890 Preface, bolstered with reference to new material sent from Tasmania, but there was a significant addition. Tylor was a monogenist, but he challenged the idea that the Tasmanians' 'extreme primitivism' could be result of cultural decline caused by isolation. 'Of degeneration', Tylor wrote of Tasmania, '...there is at present no evidence' (Tylor 1894: 148). Tylor understood culture to be universal and progressive. It was that 'complex whole' of customs, beliefs and knowledge that determined membership of a society' (Tylor 1871: 1). All societies however primitive - possessed culture and with it an innate potential to evolve. For Tylor, the Tasmanians' offered a singularly significant example of that potential in its earliest phase of evolution. They represented the beginning of human culture. Tylor's 1894 paper placed his evolutionary theory squarely in the centre of the monogeny/polygeny debate (Macdonald 2005: 123-134). In so doing he inspired a shift away of the focus on Tasmania from their human remains to their remnant stone artefacts to illuminate the beginnings of cultural evolution.

By the early twentieth century most museums with an anthropological purpose in Britain, and some beyond, had at least a small number of Tasmanian Aboriginal stone implements. Many possessed far more. By sheer volume, stone tools make up the largest part of the overseas Tasmanian Aboriginal collections. Museums in Brighton, Bristol, Belfast, Cambridge, Leeds, Liverpool, London, Manchester, Oxford and Sheffield each house over a hundred Tasmanian stone tools; there are collections in Basel, Bern, Brussels, Copenhagen, Geneva, Göteborg, Leipzig, Leiden, Paris, Rome, and Stockholm; and further afield: Cape Town and Hawaii. Almost all of these collections were formed by resident Tasmanians and sent either as donations or by request. Institutional exchanges were also common, as curators sought to obtain a 'type-set' of implements, or to off-load surfeit collections. ${ }^{6}$ Ernest Westlake was probably the first British man to go to Tasmania with the purpose of collecting stone 
artefacts in 1908, and formed what is possibly the largest single collection of its kind: over 13,00o stone artefacts, housed in Oxford University's Pitt Rivers Museum since 1923 (Taylor, Jones and McCarthy 2013). It is both profound as well as accurate to reflect that this vast accumulation of rock was inspired by just one stone.

The eagerness to accept large numbers of stone was not always so wholehearted. When The Reverend C. G. Wilkinson, principal of Launceston Grammar School, sent over sixty artefacts to the British Museum in 1901 they were acknowledged with gratitude, but Keeper Charles Read thought it 'rather illjudged' to claim the Tasmanian Aboriginal people were 'associated with paleolithic man any more than with any other race or similar culture period'. 7 Read offered no explanation for his contrary opinion, adding only: 'this is a large question to which I shall not enter at present'. But it is possible that from the array and variation of Tasmanian stone work Read had been able to study in the British Museum, he could find no clear reason to consider the Tasmanians as especially simple. Nonetheless, due largely to Tylor, the idea of Tasmanians as the most primitive culture on earth was one of remarkable longevity. There was, however, at least one collector who shared Read's doubt.

\section{Q'JUSTICE DONE TO MY BLACK BROTHERS'}

In 1898, Joseph Paxton Moir the manager of the Taroona shot tower south of Hobart, wrote to the chief Hobart scholars of Tasmanian Aboriginal culture:, Alexander Morton, government statistician and geologist, R. M. Johnston and historian James Backhouse Walker. Moir explained that being surrounded by former Aboriginal 'camping grounds' that in his 'spare time' he had been able to 'dig over' some sites. ${ }^{8} \mathrm{He}$ had found stone tools that demonstrated that the Aborigines were 'skilful and ingenious tool makers'. They could 'control the break of the stone so as to make ... curves... straight breaks and edges, and ... angles ...according to the intended use of the tool. ' 'We live 4 miles from the train terminus', he told them hopefully, 'but you would enjoy the walk'. ${ }^{10}$ They did not come; they did not even respond to his letters. ${ }^{11}$ So it was that Moir decided to write to one of the most eminent anthropologists of the day.

Moir admitted to Tylor that the only work he had read on the subject of Tasmanian anthropology was Tylor's 1894 paper. He had in fact avoided reading 
other material in order to 'prevent' his thinking from being 'warped', and leaving him able to offer some original thinking on the subject. ${ }^{12}$ While never losing their respectful tone, Moir's neat and careful letters persistently drew Tylor to one main argument: that the Tasmanians' cultural status should not be regarded as too low. He agreed that the Tasmanians were Palaeolithic, but came late in the culture phase, and were in fact 'on the eve of the Neolithic Age'. ${ }^{13}$ Moir described an implement as having ' 24 chips to the inch', and carefully sketched it so that Tylor might notice this when he was to later receive the artefact. Moir observed that it took 'more skill...to break a stone into shape than to grind it'.14 Moir drew pictures of hands cupping axes to demonstrate a lack of handle was no disadvantage. ${ }^{15}$

His letters to Tylor, written over eight years, are long and well thought out. Some were formal essays. Moir not only described the stone tools and where and when he found them, but drew them, suggesting their various uses, how they might have been held and creating numerous typological categories. He also sent Tylor many specimens for his collections. Moir complained to Tylor, 'very few here take any interest in Paleolithic matters and the members of the Royal Society (Tas.) do not care to acknowledge my communications because I do not belong to their circle or clique'. ${ }^{16}$ Moir had read their thoughts accurately. Walker admitted privately to Roth that he found Moir's ideas 'fanciful' ${ }^{17}$

But Tylor also wrote to Roth. In his opinion, Moir's discoveries should be included the second edition of The Aborigines of Tasmania. Tylor was particularly interested in a new type of tool Moir called a 'duck bill', named after its beak-like nodule. Moir imagined it would have been used for fine wood design. ${ }^{18}$ Roth responded to Tylor: 'I am...in the dark as to what the Tasmanian could have used a duck bill stone for'. ${ }^{19}$ But Tylor insisted, and as he told Roth, Henry Balfour, curator of the Pitt Rivers Museum, agreed. Four illustrations of Moir's tools (including the 'duck bill') featured in the second edition (Roth 1899: 145). ${ }^{20}$ Roth later complained to Walker of the inclusion: 'I have (strictly entre vous) very grave doubts but both Tylor and Balfour are against me and so I give in to superior judgment'. ${ }^{2}$

In the Preface to the new edition, Tylor wrote, with reference to Moir, that the Tasmanian stone tools showed the 'delicacy...as seen in neolithic work' (Tylor, 1899: viii). The following year, he presented one of Moir's letters to the Royal Anthropological Institute, stating that '[f]or variety of form and purpose and 
ingenuity of chipping, the Tasmanians hold their own against Australian implements' (Tylor 1900: 258).

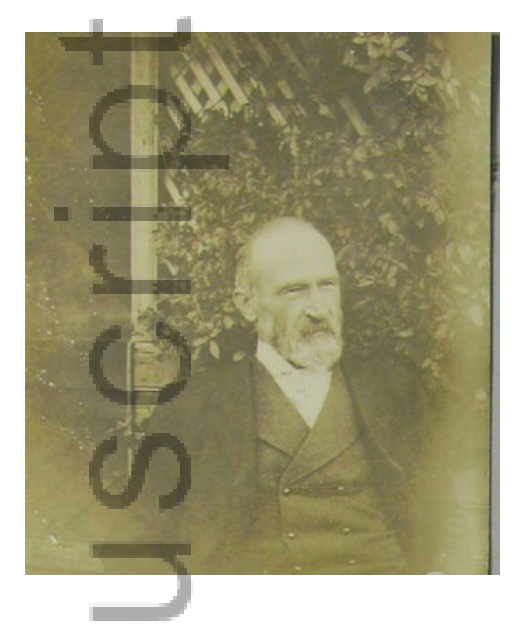

Figure 1 Joseph Paxton Moir sent this photograph of himself to EB Tylor in 1905 after seven years of correspondence. Pitt Rivers Museum: Photograph Collections, Westlake Collection: 1998.544.1. Accessed online via: Stories in Stone: an annotated history and guide to the collections and papers of Ernest Westlake (1855-1922), Image 14, WESTooo20, Series 2: http://www.westlakehistory.info/viewer/WEST/item/WESTooo20/14

After nearly seven years of correspondence Moir wrote with gratitude to Tylor that he had placed the Tasmanian Aboriginal people '... in a better light and exhibited their capabilities as clever and ingenious stone-breakers....':

This result alone is sufficient to repay and qualify me for my interest and work in this Tasmanian phase of the Stone Age (partly perhaps because I am a white Native of Tasmania and wish justice done to my black brothers). ${ }^{22}$

Moir sought reparation in evolutionary science. He made the designation of Late, rather than Early Palaeolithic an act of compassionate reparation. If the colonised 
society was not so 'low', Moir's logic seemingly followed, and then their destruction could not so easily be vindicated as natural. Tylor's first aim was not to vindicate colonisation, but by reducing Aboriginal society to the representatives of Europeans' distant past he facilitated that aim by extension of logic. But the logic has an inherent contradiction. In order to make the Aboriginal artefacts represent the culture of a distant time and place, Tylor had to abstract Aboriginal artefacts from their own historical and social context. In contrast, Moir understood the stone implements he collected within the spaces where they had been made and used; the old camping grounds, the middens and beaches, but more; he knew the stories and memories that went with those places. He knew the reasons that he was able to pick up that which was once an implement of simple use; that had been the property of someone else.

Moir sent a photograph taken in James Watt Beattie's Hobart studio of what is presumably his own hand holding a stone tool. His stiff shirt and jacket cuffs seem incongruous with the stone tool and with the person who once used it. While Moir's hand replaces the original owner's hand, it also remembers it, and its efficacy. Moir hoped to demonstrate that a handle was not essential to a useful axe. But the photograph is not only proving a point of anthropological detail; it reflects the justice Moir hoped his science could do for his 'black brothers'.

But while Tylor acknowledged the Tasmanians' 'finer' work in his Preface to Roth's second edition, he also concluded that their culture status should nonetheless be 'judged' by their 'general' character of which Taunton Scraper remained indicative (Murray 1992: 735). But his original impression, formed on seeing that first stone implement, now had a comparative evolutionary phase even more ancient than the first cave dwellers. It was the 'oldest and rudest palaeolithic implements found in Europe: the plateau-flints of Kent' (Tylor 1899: viii). It is interesting that Tylor chose to refer to the 'plateau-flints of Kent' as 'paleolithic' when their discoverer, Benjamin Harrison, the storekeeper of the Ightham village, considered them to have dated from the earlier, controversial culture phase called the 'Eolithic'.

The discovery of a Pleistocene human antiquity in 1859 had 'opened the gates' for an even deeper antiquity: scientists 'expected' to find artefacts in increasingly earlier deposits of gradually cruder style as they traced humans back to the hominids of Darwin's theory of biological transmutation (Grayson 1986: 79). While geologists could determine the age of excavated material by stratification, the emergent 
discipline of archaeology struggled to discern human-made stone tools from rocks broken by natural causes. From this inability there emerged a heated, but formative debate over the age of human antiquity as European scientists claimed to find stone tools that dated from before the Pleistocene, from the 'Tertiary' geological period, hundreds of thousands of years into the past. By the mid-twentieth century these 'tools' were realised to be what the sceptics had always claimed from the outset: naturally broken stones.

Harrison's 1885 finds were the first claims to Eolithic stone implements in Britain, and they roused considerable debate. But it was significant that the archaeologists Prestwich and Lieutenant-General Pitt Rivers considered them genuine (Roe 1981: 217). Pitt Rivers wrote to Tylor on the subject of Eoliths in 1898:

Has it occurred to you that your Tasmanian flints, the flat ones chipped only at the edge that you shewed me at Oxford, are exactly like Mr. Harrisons [sic] chalk plateau flints that he considers prePalaeolithic [sic] and calls Eolithic? ${ }^{23}$

A year later, Tylor echoed this comparison in the Preface to the second edition of The Aborigines of Tasmania. In 1905, Tylor wrote to Moir that he was working on his final book, Growth and Spread of Culture. It was to be his last effort to illustrate his monumental ideas of evolutionary human development. ${ }^{24}$ But this last treatise was never published. The manuscript in the Pitt Rivers Museum archives reveals rough notes of the first chapter entitled 'The Eolithic Age and [the] Tasmanians'. 25

It was during these final years of his work that Tylor had several plaster castes of the Taunton Scraper made, 'to give to certain museums'. At his request, the assistant Secretary and Curator of Taunton Castle Museum, H. St George Gray, sent one to Charles Read, keeper of the British Museum, describing it as 'the famous Tasmanian stone implement' from their collection. Gray added that 'Dr. Tylor never comes here (and he is often here) without asking to see our Tasmanian implement'. ${ }^{26}$ If the Eolithic Age was contentious, it was also appealing. Even its name reflected how Tylor had always seen the Taunton Scraper: the symbol of the dawn of humanity.

The Taunton Scraper had been at the centre of Tylor's thinking for forty-five years influencing the central role he played in the disciplinary transformation of ethnology 
into evolutionary anthropology. This shift is illustrated clearly by the distinction between Tylor's 1865 reference to the Tasmanians as the 'lowest tribes known to ethnology' with his 1894 'Representatives of Paleolithic Man'. More significant than the abandonment of the word 'ethnology' is that the Tasmanians are no longer 'known', but had become 'representatives' standing for another time, place and people, and not for themselves. As geologist W. J. Sollas wrote in his 1911 book, Prehistoric Times: 'the real value of what little we know about the Tasmanians lies in the analysis it provides ... of the earliest relics of Palaeolithic man' (Sollas 1911: 70).

If ethnology had aimed to tell a global story of human diversity or unity across space, then anthropology became a science by 'shedding' this historical vision; it 'defined itself against history', in order to interpret culture according to 'general laws across time' (Griffiths 1996: 25-26). Societies were organised along an 'axis of assumed structural ideational archaism', with Victorian European society occupying the most advanced end of the spectrum, the Tasmanians at the other (Keen 2000:

89). It was, Sollas admitted, 'a wilfull [sic] anachronism', willful presumably for the thousands of years and kilometres that separated the two societies (Sollas 1911: 70).

It seems contradictory that a theoretical framework that collapsed time and space should have emerged out of the disciplines that measured the past. Geology had offered up the vast expanse of time required for the transmutation of species; paleontology demonstrated that theory by revealing extinct life forms; and archaeology, born out of the discovery of human antiquity, was the first discipline to map culture in the 'ages' of Stone, Bronze and Iron and compare them with living societies (Keen 2000: 79). As anthropology adopted this framework, evolution became determined rather than random, as it was within Darwin's biological definition. Nonetheless, Darwin succumbed to this progressive view of culture (Griffiths 1996: 10).

Tylor not only called primitives 'representatives' of earlier culture phases, but also the 'survivals'. In the case of the Tasmanians, the term offers up a strange irony. To be 'survivals' and extinct required the Tasmanians be at once outside history and also the subjects of its tragic reality. But within the framework of nineteenth-century evolutionary anthropological theory, time and history were not the same. If the Tasmanians had occupied their 'remote corner' since the 'early ages', as Tylor put it, they had 'gone on little changed'; they had been locked in a Palaeolithic, or even 
Eolithic stasis. The only history that Tylor acknowledged the Tasmanians possessed had ended in 'total extinction'. Indeed, being 'confidently declared extinct', was for the Tasmanians, 'the only alternative to being timeless' (Griffiths 1996: 25-27).

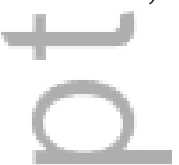

\section{THE LAST TASMANIAN}

During the 1890 s the Aboriginal population of Tasmania was active, vibrant and growing. There were over a hundred indigenous peoples centred on Cape Barren Island in the Bass Strait. Their community had emerged out of the colonial maritime frontier opened by the sealing trade that operated from the late 1790s. European 'Eastern Straitsmen' made the islands their homes from the 1820 s. Their wives, the tyereelore, were chiefly from the Coastal Plains and Oyster Bay Nations of the northeastern coast of Tasmania. Their children grew up knowing their fathers' and mothers' languages and traditions. It was what descendant of four tyereelore and their Straitsmen husbands, Patsy Cameron, describes as a 'blending of two cultures' from which sprung a 'new lifeworld and a new peoples of the islands' (Cameron 2011: ix, 97-122, 154).

At the southern end of Tasmania lived Mrs Fanny Smith who was born on Flinders Island in 1834 or 1835 to Aboriginal parents. She was a cultural and spiritual leader of her community at Irish Town, later Nicholls Rivulet. By the 1890 s her eleven children had families of their own. They continued to remember Mrs Smith's language and traditional practices. There were also other Aboriginal families at this time living in various parts of Tasmania. (Ryan 2012: 275)

These communities were not, however, considered Aboriginal by their contemporary white society. Extinction was a concept based upon an understanding of blood as both a conveyor of racial distinction and as being quantifiable: it could be mixed and measured in parts to create 'half' or 'quarter-castes', but these hybrids could not, in this logic, represent the original, 'pure' race. As Russell McGregor explains, the extinction of the Tasmanians 'referred not to the demise of all persons of ... Aboriginal descent, but to the disappearance of a supposed racial entity' (McGregor 1997: 51, 53). 
But it was in keeping with this logic that in 1889, Tasmania's government printer, James Barnard wrote to the journal, Nature, that Mrs Smith, then aged 55-years, was 'upon her own testimony' a 'full blood' Aboriginal and 'the 'last survivor' of her 'race'. Mrs Smith's parents who were both 'undeniably aboriginals', asserted Barnard, a fact which had been endorsed by Tasmania's Parliament. (Barnard 1889: 43). Henry Ling Roth read Barnard's letter with fascination and incredulity.

Roth was a businessman whose work had taken him to Eastern Russia, British Guiana, and, from 1878, a ten-year residency in north Queensland consulting for the sugar cane industry. This inspired and paralleled a range of scholarly interests from entomology to anthropology. The Aborigines of Tasmania, was his first book and Roth sought to 'establish complete authority' over the subject. (McDougall 2007: 47). Tylor praised Roth's, 'long and conscientious labour' to compile 'to absolute completeness ... the notices scattered through voyages, histories, colonial documents and ... first-hand information, however fragmentary' (Tylor 1890: viii).

It was a desire to check the veracity of Barnard's claim in his book that initiated his first letter to James Backhouse Walker in Hobart. By then Roth's book was in press, and it was too late to include any new findings. But Roth's interest in Mrs Smith instigated eight years of work on a second edition, which was directed and informed by Walker's extensive assistance from 1891 to 1899.

Walker's first scholarly interest was the history of Tasmania's discovery and settlement. He was also a busy barrister, an active member of the Royal Society of Tasmania, a member of Tasmania's Board of Education, its university's second vicechancellor, and a Trustee of the Public Library. A friend and advisor to pastoralists, politicians and premiers, Walker's house was an intellectual and literary centre of Hobart (Felton 2102: 1, Smith 1976).

Roth wrote to Nature that Barnard's claim lacked a description of Fanny's 'features' detailed enough to determine her as a 'pure-bred aborigine' (Roth 1889: 105).To this end Roth asked Walker for help acquiring a 'fairly large portrait' photograph of Mrs Smith ('full face and profile'); for hair to be taken from her head, her armpits ('if it grow there') and 'from the pubes'; and, a 'concise scientific description of her physical characteristics'. The request went further: 'On her death her skeleton should be preserved and sent home to be examined by an expert ... it 
could be consigned ... to the agent general in London so as to ensure its safe return to Tasmania'. ${ }^{27}$

The astonishingly insensitive request was in keeping with the blatant descriptions and images of stolen Tasmanian Aboriginal ancestral remains reproduced in Roth's book. His presumption this theft was appropriate academic practice resounds in his use of the word 'home'. It is not that he considers England to be Mrs Smith's home (he suggests plans for her body to have a 'safe return'), but the home of 'expert' study, and, no less presumptively, the 'home' of Hobart-born Walker. The word bespeaks the condescension of a generation and of an Empire.

Walker's response was politely understated. He advised that the procurement of Mrs Smith's skeleton, was 'a rather a delicate matter' that would pose 'some difficulty'. (He was perhaps remembering the public uproar that followed the dissection of Lanne's body in 1869.) Walker was probably correct when he surmised that Mrs Smith's 'husband might very likely object to allow the dissection of her body in case of her death'. Walker did, however, think he could attempt Roth's others requests. ${ }^{28}$ But more than a year passed before Walker reported to Roth that Mrs Smith 'is yet an unattained object...' The phrase reaffirms the dehumanising effect of Roth and Walker's correspondence and of the ideas of physical anthropology that could reduce a living person to the value of her body and its parts. After another six months Walker had delegated the task of obtaining a photograph of Mrs Smith and continued to supervise the issues from afar. ${ }^{29}$ Indeed, he did not actually meet Mrs Smith until after Roth's second edition had been published in 1899.

The fact Walker was in 'no doubt' that Mrs Smith, was a 'half caste', perhaps made him less inclined to urgency. But it was also because Walker's time was divided, and at times his health was compromised. Walker sometimes found it hard to carry out research for Roth and his responses were often protracted. But these difficulties made his efforts all the more significant. Walker's 'unsurpassed knowledge', and 'never failing keenness', Roth acknowledged, were of 'inestimable value'.30 At Roth's insistence, Walker was listed as assistant author in the frontispiece of the new edition (Felton 2013: 24, Mcdougall, 2007: 51).31

One of the first tasks that Walker was inspired to complete for Roth was to write a brief history of settlement, a subject he thought had suffered 'much misrepresentation' along with a comprehensive guide for reading 'the principal 
writers of the Aborigines'. ${ }^{2}$ Walker had more a comprehensive knowledge of the Aboriginal records than Roth, and a local's grasp of events and politics. He sought to caution Roth of the unreliability of the historical sources regarding the Aborigines. The journals of the French explorers who made first contact were 'saturated' with 'fashionable fancies of the Rousseau school'; the oldest remaining settlers remembered Aborigines only as 'treacherous foes' owing to the 'deadly feud' that began around 1824; G. A. Robinson, Government Conciliator 'who brought in the blacks' was the only writer who had known the Aborigines 'in their wild state', but his voluminous reports included too many 'personal adventures'; and, finally, the efforts to record their customs when they were incarcerated on Flinders Island came thirty years after settlement, by which time the Aborigines had 'picked up' many new 'ideas and practices'. 33

Walker's parameters were rigorous. The idea of extinction challenged certainty; the supposed absence of living Aboriginal people meant there was no measure against which to test the authority of any fact gleaned. But the challenge held appeal. It turned historical research into relic hunting; the search for the last vestiges of something pure but lost. Indeed, the idea of extinction was a large part of what drove Roth and Walker's long and shared interest in the Tasmanians.

While the written sources were inherently unreliable, the physical remains of the last 'wild' Aborigines had, according to Walker's standards, retained their authenticity. At his instigation, Walter Harper and Arthur Clarke examined nineteen Aboriginal skulls housed in the Tasmanian Museum in Hobart. 34 Roth sent instructions on how to determine craniometrical capacity: they poured lead shot into the upturned skulls and then transferred into a glass gauge, also sent by Roth. 35 Three skulls were rejected from the study as belonging to 'half-castes', and three because they were not known definitively to have belonged to Tasmanians (Harper and Clarke 1897). ${ }^{36}$ It was the collections' largely vague provenance that led Walker to spend over a year trying to access a collection of six Tasmanian Aboriginal skulls in the possession of Edward Cotton whose family had lived at Kelvedon on Tasmania's East Coast since 1829.37 The skulls in Cotton's possession were 'most desirable', Walker told Roth, as he knew 'the history of each, and they are undoubtedly Tasmanians'. But, he complained, no 'competent person' had time to travel up to the East Coast to measure them. ${ }^{8}$ Walker's own efforts were hampered by illness and 
time constraints. ${ }^{39}$ Bishop Montgomery finally extracted a promise from Cotton to send the skulls down to Hobart. '[I]f only these could be measured in time for publication', Roth worried, but Cotton did not keep his word.40

When Walker learned that Roth's few samples of Aboriginal hair had been lost by the Pitt Rivers Museum, ${ }^{41}$ he tried to extract from a matted, and 'much ochred', lock of hair that he had, a few strands long enough to be of 'use'. ${ }^{2}$ The hair had belonged 'either' to Wooreddy or Mannalarganna, Aboriginal leaders who had negotiated with the colonial government on behalf of their people. Roth received the hairs with sanguinity: 'it is really sad to dwell on their fate'.43 But he was 'extremely obliged', to later receive a piece of Truganini's hair that Walker had secured from Clarke. He thought it a 'most interesting relic' and promised it would be 'carefully preserved'. ${ }^{44}$

The vestiges of the supposed extinct Tasmanian Aboriginal people were given far higher value by both Roth and Walker than any information remembered by, or concerning, their living descendants. Beattie offered to send Roth a 'very successful' photograph of five Cape Barren Islanders taken by Bishop Montgomery in 1893: 'all the pure halfcastes now alive'.45 The curiously contradictory term referred to the adult children of the first tyereelore and Straitsmen island settlers, but Roth was not interested in acquiring the image. He, with Walker's guidance, ignored the Islander community and overlooked the significance of their enduring cultural knowledge. When Roth asked Walker to obtain an Aboriginal shell necklace, Walker explained they were 'commonly for sale here' but since the 'half-caste' islanders made them, they were not 'genuine'. He thought there were only about three 'native' necklaces left in the colony. ${ }^{46}$ Roth passed on his wife's thanks nonetheless; she planned to display the necklace in their drawing-room. ${ }^{47}$ When Roth later asked if it was true, as he had been emphatically told in England, that there were some 'aborigines' living in the Bass Strait, Walker responded unequivocally: 'The islanders ... are not aborigines, but half-castes - a mixed breed of Tasmanian, Australian, and European, with a dash of Maori'.

While the Islanders were discounted as reliable informants, Walker considered written and oral sources from certain white colonists to be trustworthy. He took notes from second-generation settlers Cotton and G. H. Rayner on how Aboriginal people made fire (Roth 1899: 1xxxxviii, 83-84; Taylor 2008: 7-9; Walker 1900: 5).49 Walker found a hitherto undiscovered vocabulary of Aboriginal language in the journals of 
his father, George Washington Walker, recorded on his travels with fellow Quaker Missionary, James Backhouse in 1832 to Tasmania's Aboriginal settlements..$^{\circ}$ With Tasmanian government statistician and geologist R. M. Johnston and W. N. Hurst of the Lands Office, Walker had offered Roth a new map of Aboriginal tribal boundaries and place names (McDougall 2007: 53). ${ }^{51} \mathrm{He}$ took a journey with Beattie and Johnston to an Aboriginal quarry that Rayner insisted was 'unknown'. ${ }^{2}$ This was the only journey Walker carried out for Roth. He had tried hard to travel to Cotton's at Kelvedon, but he had never showed much interest in going to see Mrs Smith, having little doubt she was a 'half caste'. Instead, Walker had passed on Roth's requests for Mrs Smith's physical details to his friend, J. W. Beattie. 53

Beattie had been 'intensely' interested in the Tasmanian Aboriginal people for many years. His large Hobart photographic studios displayed a 'very complete collection' of their photographs, among other historical artefacts. He promised Roth to secure photograph of Mrs Smith soon as she was often seen in Hobart. ${ }^{4}$ He was still waiting six months later. ${ }^{55}$ By the time a year had passed, Beattie sent his brother down to Port Cygnet, 'with full instructions' and orders 'to stay till he gets her to sit, if it takes a fortnight'. He went with several photos of 'her people' to use 'as a bait': should she agree to be photographed again in Hobart, she would be given more. ${ }^{6}$ Mrs Smith could not be enticed to Beattie's studio, but his brother successfully procured the images and hair in Port Cygnet. When Roth finally received them, he found he agreed with Walker: 'I do not think she is a pure aborigine'. But as he was still waiting on an expert report on her hair sample, Roth wrote that he 'would rather this opinion is not yet made public' (Roth 1899: 1xxxvi). ${ }^{57}$ In the interim, Roth sought descriptions of Mrs Smith's 'mental' and 'physical' details including her blood status. Beattie dutifully sent out letters to those who knew her well requesting this information..$^{8}$

The two of Mrs Smith's friends who responded would not condescend to Roth's scientific terms. Former Wesleyan parson of Port Cygnet, A. J. Holden, stated that 'physically' Mrs Smith was a 'marvel'; 'mentally', she was 'very bright'.59 Mr A. Geeves of Hobart described his friend as a 'Christian woman who was 'well respected...by all who know her'. ${ }^{60}$ Both men agreed Mrs Smith was a 'full-blood' Aboriginal. ${ }^{61}$ 'She certainly believes herself to be', wrote Holden. But if her own testimony could convince Roth he would not have persisted with his inquiries in the first place. He 
instead asked Beattie to try and get a description of Mrs Smith's teeth. Beattie responded with incredulity that her friends, 'excuse themselves by telling me it is a rather a delicate matter!'62

One of Mrs Smith's friends did tell Beattie how Mrs Smith spoke of her people as 'telepathists': they 'knew when any accident happened to any relative'. Her mother would also 'sit and look at the stars' and 'give them names'. They had 'religious belief: '...good and evil spirits, blessing or hindering' ${ }^{63}$ But Roth reported none of this. Nor when he learned from both Walker and Beattie that Mrs Smith planned to go to England 'to see Queen Victoria' he did not express much interest. ${ }^{64}$ (Mrs Smith never made this visit). In early 1898 , Roth presented his conclusion on the matter to the Anthropological Institute: Mrs Smith's facial features were clearly that of a 'halfcaste'. ${ }^{65}$ It was, he reflected to Walker; 'a result I must confess a little disappointed at'. ${ }^{66}$ To discover the last Tasmanian Aborigine would have been an academic coup.

These disturbing efforts reveal Roth and Walker's research as a kind of morbid relic hunting. Walker understood that Roth's goal was not only encyclopedic completeness, but the acquisition of the most valuable facts and artefacts that remained from the presumably dead Tasmanian Aboriginal people. Here the concept of extinction extended beyond blood quantification, indeed it extended beyond Aboriginal bodies. It created in its relief the idea of something pure but lost; something destroyed not only by death and miscegenation, but the imperfection of historical accounts and tainted or vanished memories. It made the anthropology of Tasmanian Aboriginal people not just one of salvage, but also of careful interpretation, sifting and even rejection: not just the 'half-caste' skulls but also their contemporary necklaces, even the, 'half-castes' themselves. These were perceived not as evidence of a continuing and living Aboriginal culture, but the evidence of inauthenticity and absence. Such interpretation required expertise. The idea of extinction created hierarchies and cliques of knowledge. Walker sat at the centre of that 'clique' as Moir had termed it, and his influence was considerable.

Hobart, not England, was Walker's true 'home'; his own social and intellectual hub from which he, nor Beattie, rarely left. Engaged in their businesses, they, like Roth, carried out most of their research by correspondence. He was prepared to travel only where he deemed the information would be worthwhile. Moreover, Walker was aware of the rich collection of manuscripts, memories and collections that were already to 
hand in Hobart museum and private collections. Nonetheless, Walker often wished he could travel further afield. He even urged Roth to visit.

'Why not take a six month holiday, and come and study the Tasmanian question on the spot?', Walker asked Roth in 1897: 'You would learn more in a month here, than in years of correspondence. ${ }^{67}$ By this time Roth had been working on his second edition of The Aborigines of Tasmania for six years, and would do so for another two, incorporating the research that Walker carried out on his behalf. Despite the sagacity of Walker's advice, Roth did not go to Tasmania. Roth could not leave his business, his next book, his new wife and their baby son. ${ }^{68}$ But nor did Roth need to: he had in Walker a meticulous expert. Walker never assumed himself to be a professional.

While he directed and influenced Roth's work, he understood his role was to underpin Roth's ideas, and in particular his goal to determine the Tasmanians' extinction.

Walker and Roth believed in their thoroughness, tenacity and high scholarly standard. When Walker finally received the second edition of The Aborigines of Tasmania he was 'exceedingly pleased'. He congratulated Roth for having 'the final word on our unfortunate Aborigines' and leaving 'very little indeed for any aftercomer to glean.' 69

It was not until after Roth's second edition was published that Walker met with Mrs Smith. With Bishop H. H. Montgomery they recorded her Aboriginal songs onto a gramophone. 'It seemed to me to be soft and pleasing...', Walker reflected, but he did not expect to gain any more 'that is valuable' from her. He considered the greatest benefit of meeting her was confirming the illegitimacy of her own testimony:

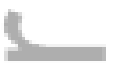

If you could have seen her, you might have made your paper much stronger. She has a pink tinge in her cheeks, and is manifestly a half caste. The Bishop said so at once...70

But Roth nềver saw Mrs Smith's 'pink' cheeks. He determined her blood status in Halifax from samples of her hair, physical descriptions made by others, but foremost from the photograph sent by Beattie. Photography already had an established place in the scientific definition of Tasmanian Aboriginality. The portraits of residents of 
Oyster Cove photographed from the 1850 s had been reproduced widely in books, postcards and albums from the 1870 . They marked what Tasmanian Aboriginal historian and artist, Julie Gough observes was an 'abrupt and dehumanising shift' in the photography of Tasmanian Aboriginal people from 'art' to photography as 'a tool of science'. As such they played a key part in the 'official determination not to recognise' Aborigines living in the other parts of Tasmania (Gough 2014 pp 36-37).

Roth was familiar with the Oyster Cove images; many featured in his book. But he 'saved' perhaps the best-known photograph, Charles Woolley's portraits of Truganini, for the penultimate pages of the book in order that they could appear along side those of Mrs Smith and thus 'force the comparison'. It was an effective ploy (McDougall 2007: 57). Reviewer Andrew Lang agreed that Roth's evidence was 'conclusive, and instantaneous': Mrs Smith's face 'might pass for a true blue, jolly, British landlady', but Truganini's face was, 'black, hideous': the 'face of a pure Tasmanian savage ... the last of a people who... still lived... the life ...of the Palaeolithic age - the mammoth period of Europe' (McDougall 2007: 57-58). Lang converged Tylor's concept of the Tasmanians as the representatives of the Paleolithic with Roth's determination of extinction. He then compared the Tasmanian Aboriginal people to the British colonists whom he described as evidently being a race of 'superior endurance, and intelligence'.

Lang did more than converge Tylor's idea of the 'Palaolithic' Tasmanians with Roth's assertion of extinction, he questioned Tylor's comparative evolutionary framework. How could the Tasmanians 'represent' the early Europeans when they were extinct? For the Europeans had been a 'white race, with all its superior endurance, and intelligence, or capacity of becoming intelligent' (in McDougall 2007: 49). In order to celebrate British racial superiority Lang not only has to challenge the universality of Tylor's definition of culture, he has to manipulate his notion of the representative 'Palaeolithic' away from the comparison between the stone tools, to become part of Roth's interest in racial typology determined by studies of hair samples and photographs. But Tylor had not sought the physical representation of the Palaeolithic, only its material cultural counterpart. For him the Tasmanian Palaeolithic did not die with Truganini, but lived conceptually, in the continuing presence of their stone artefacts. 
This distinction between Roth's and Tylor's research goals is realised in their correspondence. To determine that Mrs Smith was not the 'last' Tasmanian required years of indefatigable letter writing. Tylor's goal hardly required any correspondence at all. His designation for the Tasmanians was confirmed through the repeated visits to the Taunton Museum. While Moir, 'surrounded by camping sites' unearthed unusually well-made tools, Tylor could acknowledge these variances with interest even to the chagrin of Roth - without it disturbing his larger thesis.

The difference between the researchers' objectives is further realised in their approaches to Tasmania's past. Roth was intensely interested in that history, both as a mine for anthropological information, and in its outcome, extinction. Tylor was not drawn to explore the end of Tasmanian Aboriginal history. Rather, in one abstracted artefact, he sought to discover the beginnings of human history. This encapsulation not only made the Tasmanian Aborigine people recent past largely irrelevant, it denied them any real history at all.

\section{EPILOGUE: ‘A REAL, DEEP PAST’71}

'Traditions die hard', wrote Australian archaeologist John Mulvaney in 1961. He reflected while Tylor's conclusion, drawn from the single Taunton Scraper, had lead to a persistent and widespread belief that the Tasmanian Aboriginal peoples' stonework was inferior to that of Australia's mainland Aborigines. But, Mulvaney asserted, the Tasmanians' stone tools included 'specialised type and fine craftsmanship'. His reference was to the 1925 paper by Henry Balfour, Keeper of the Pitt Rivers Museum which was based on the study of the vast collection of Tasmanian Aboriginal artefacts formed by Ernest Westlake from 1908-1910 (Mulvaney 1990: 45).

Balfour concluded that the Tasmanians' cultural status had been 'marked too low'. He thought that to do 'justice to the native potentialities', it was important to draw conclusions not from their 'general' work (as Tylor had done), but from their 'highest attainments'. Balfour 'put forward a plea for a correlation' between Tasmanian stonework and Europe's middle Palaeolithic period; the 'post-Mousterian culturephase, to wit the Aurignacian' (Balfour 1925: 3-14). Balfour thus declared 'the so- 
called "Eolithic Tasmanian" is a pure myth' (Balfour 1929: 315).

Mulvaney thought Balfour had been the 'the first' to demonstrate the full capabilities of Tasmanian stone making, and remained in 1961 the most detailed on the subject (Mulvaney 1990: 45). But Joseph Paxton Moir had pre-empted Balfour. It is possible that Balfour read not only the published accounts of Moir's correspondence to Tylor, but the letters themselves, which were accessible to him in the Pitt Rivers Museum (and may explain how Moir and Tylor's correspondence came to be stored with Westlake's papers). Certainly Balfour owed to Moir not only the conceptual basis of his thesis, but the identification of some of the tool types he refers to, including the 'duck-bill scraper' (Balfour 1929: 320). One of the clearest echoes of Moir's writing - if perhaps coincidental - is Balfour's use of the word 'justice', for it was 'justice' that Moir hoped his efforts might have offered his 'black brothers'.

Moir's ideas had been not only outside the mainstream of British scholarship, but that also that of his own town. Yet over time, they came to be accepted by leading scholars. An important parallel is found in Alfred Howitt's suggestion that the Tasmanian Aboriginal people had originated from a Pleistocene Australia. The idea found some interest locally. For over a decade, stone tool collector, Alfred S. Kenyon, scoured Victoria's coastline for stone implements that might draw a typological connection between Tasmania and Victoria. In 1899, Howitt wrote to Tylor of Kenyon's findings. But Kenyon then became one of Spencer's closest acolytes, and it was perhaps under his influence that Kenyon agreed that a typological connection did not mean evidence of antiquity, concluding finally that Aboriginal people had not been in south-east Australia more than a few thousand, or even few hundred, years. Most of Kenyon's fellow members of Victorian 'stone circle' shared his conservatism well into the twentieth century (Griffiths 1996: 72-79).

In 1923, T. W. Edgeworth David extended Howitt's ideas, suggesting that the simplicity of Tasmanian Aboriginal material culture and the absence of the dingo pointed to an older Pleistocene link with Australia. But his thesis was largely rejected, in favour of relatively recent migratory sea journeys from the Melanesian region, (although leading Australian archaeologist, Norman B. Tindale argued that the Tasmanians' migration did not necessarily negate a deep history) (Pulleine 1928; Tindale 1937-41; Wood Jones 1935: 11). The debate turned increasing attention to 
Tasmania's north-west corner to determine either a former link to the mainland, or an older migratory route. Stone tool collectors had found surface artefacts from the area since the late nineteenth century. From the early twentieth century amateur archaeologists followed with shovels, attempting to determine a chronological sequence (Jones 1971: 36-52; Pulleine 1928; Tindale 1937-41). John Mulvaney argued finally that the area required 'systematic excavation' (1961: 48).

This is what Cambridge graduate, Rhys Jones set out to achieve in December 1963 (Mulvaney 2001: 19). The first professional archaeologist to carry out fieldwork in Tasmania, Jones's carbon-dated sequencing effectively solved the Tasmanian 'problem' and confirmed Howitt's contention (Jones and Meehan 2000: 40). But it also raised a new question. His sequencing revealed that from 3500 years before present that there were no discarded scale-fish bones in the midden sites. This suggested to Jones evidence that the Tasmanian people had, without ostensible good reason, ceased catching scale-fish. They had seemingly become 'simplified' (Horton 1979: 170; Jones 1971: 603, 620; Jones 1978: 26-27). Jones extended the idea to a lost ability to make fire. He then pointed to a biogeographic cause: 'The world's longest isolation, the world's simplest technology'. Continuing the presumption that the Tasmanian Aboriginal people were extinct, Jones posed what became an infamous question: even if Tasmania had never been colonised, had the Aborigines been nonetheless 'doomed to a slow strangulation of the mind? (Jones 1977: 197, 202-203). The idea was repeated, to wide controversy, in Tom Haydon's popular 1978 film The Last Tasmanian.

The film was launched just as the Tasmanian Aboriginal community began a struggle for recognition, rights to land and education that was characterised by the politics of radical self-determinism. They were outraged not only by the reiteration of their extinction, but Jones's supposed reasoning that it would have happened 'anyway' (Langford 1983: 5; Mansell 1978: 2; Ryan 1996: 254). They were joined by the academy, whose members accused Jones of ' $19^{\text {th }}$ century racist ideology' (Bickford 1979: 14); 'social Darwinism,' (Bowdler 1980: 335) and of being one of the many 'Apologists for an Extermination Policy' (Ryan 1985). Lyndall Ryan restated this critique in 2012 as 'scientific racism', after Rutledge M. Dennis's definition (1995), listing Jones, with Tylor, in a progression of scholars who have, since the 
1850 s concurred that the Tasmanian Aboriginal people had always been a 'doomed race' (Ryan 2012: $x i x-x x)$.

It was this critical approach that helped ensure the wider recognition of Ryan's ground-breaking acknowledgement in 1981: 'the Tasmanian Aborigines have survived' (Ryan 1996: 257). Ryan restated this opinion in 2012 as part of her response to Keith Windschuttle's accusation that she had fabricated historical evidence. Ryan countered that a few tangled footnotes were never the real 'tinder' that generated the 'heat' of the 'history wars'. It was that her history of Tasmania was 'deeply influenced' by the successful Aboriginal campaign for the recognition of their survival (Ryan 2012: xxii-xxiv). Her point seems well illustrated when Windschuttle borrows Jones's allegorical ‘slow strangulation' of the Tasmanian Aboriginal cultural 'mind' to argue that their society was also morally regressed, being 'so internally dysfunctional' that it was 'not surprising that when the British arrived, this small, precarious society quickly collapsed' (Windshuttle 2002: 386). But Jones's dissertation expounds without restraint upon the culpability of the British, going so far as to compare colonial Tasmania to the Holocaust (Jones 1971: 2, 8-9). Jones was inspired by a wider anti-colonial movement to explore a sense of national culpability in Tasmania's past, with Truganini as a figure-head for shame (Ryan 1997: 161-165). Haydon's film had the by line 'the story of the swiftest and most destructive genocide on record'.

But there is an echo between Jones's and Tylor's ideas (McNiven and Russell 2005: 64-66; Murray 1992: 738; White and O'Connell 1982: 170). For Tylor the Tasmanian Aboriginal people were the 'lowest' culture, for Jones they were 'simplest'. Indeed, Jones went further; he thought the Tasmanian Aboriginal people were unable even to make fire, an idea which Tylor had refuted outright (Tylor 1964: 249250). Moreover, Tylor had rejected the notion of regression and degeneration. For the ideas of 'low' and 'simple' are not synonymous. The first excludes a history; the latter depends upon it. Jones's supposed regression had not been fast, and its starting point was in the deep past. Indeed, its depth further explained simplicity: Jones, like Edgeworth David, saw in Tasmania an older vestige of a pre-Pleistocene Australia (Murray 1992: 738). As Jones himself put it, separating him from Tylor was a vast quantity of time and space:

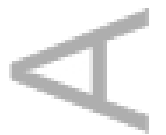


We seem once more to be turning back to the classic problem of the Tasmanians as seen by Tylor. Can we now look to the Tasmanians, not so much as the representatives of Palaeolithic man, but of late Pleistocene Australian man? (Jones 1971: 630)

Jones was suggesting a shift of continents and the realisation of an Australian antiquity. He did not continue Tylor's metropolitan and anachronistic view of Tasmania, nor the justification of colonisation that such a view has been assumed to hold. Jones continued an antipodean view of Tasmania, in which archaeologists, since Howitt, had looked to the island as a key to the question of their own country's antiquity. Jones had effectively solved the 'problem of the Tasmanians'.

But solving that older 'problem' 'paled into insignificance', following the discovery in 1981 by Jones and others of a Pleistocene human occupation in southern Tasmania (Murray 1992: 739). The Kutikina excavations, Jones explains, revealed the distinctive culture of the 'southernmost humans on Earth', which had changed when the Pleistocene ended and forests enfolded grassy plains and higher seas flooded coasts. 'The Aborigines of Tasmania', Jones announced, 'long constructed as an abstract frozen metaphor for Palaeolithic man, are now seen as inheritors of a deep real past'. The shift away from Tylor's metropolitan view was total, and yet it recalled that older perspective in a new way: Tasmania now shared an antiquity equal with that of Palaeolithic Europe, making it possible, Jones explained, to realise a collective story of global migration and adaptation (Jones 1995: 423, 438-439, 441; Jones 1990: 290).

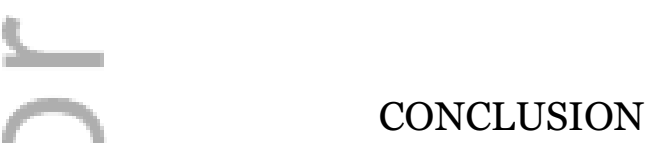

One of the most durable legacies of nineteenth-century British anthropology has been the prolonged power of the symbiotically fused ideas of the Tasmanian Aboriginal people as 'low' and 'extinct' to justify and celebrate British racial superiority. This has been sustained even when expressed within the context of shame. For the melancholia voiced over the Tasmanians' demise was at its inception demonstrably questionable in its morality, being as often a soliloquy to the loss to 
science, or the manifestation of a society so advanced it could question the cost of its progress to others less fortunate (Lawson 2014: 162-164, 109). Thus when extinction was substituted with the accusation of genocide in late twentieth century it could be mistranslated into colonial apology, and yet become rich ground for conservative criticism in the early twenty-first century.

While fused in their expediency, when returned to the level of personal correspondence, the two anthropological ideas of 'low' and 'extinct' emerge as separate research projects. The distinction is at first mundane: Tylor was not interested in acquiring crania nor in ascertaining the tightness of hair curls; Roth did not have a chief interest in whether Tasmanian stone tools were hafted, ground or chipped on both sides. But the distinction extends to the conceptual: in Tylor we find the search in Tasmania for the representative beginning to human cultural evolution; in Roth we find the search to determine their ending.

It is the colonial scholarly response to Tylor's ahistorical approach that clarifies most clearly the difference between Roth and Tylor's objectives - the antipodean aspiration to reveal in Tasmania a deep Aboriginal past offered an image in reverse of Tylor's objective to illuminate a European antiquity. As such it rejected the evolutionary comparative schema and helped to found an important new direction in Australian archaeology.

It is in realising the tensions, rather than the collusions, between colonial and metropolitan research interests and expertise, that it becomes possible to achieve a finer-grained reading of the scientific interest in the Tasmanian Aboriginal people one that moves beyond a presumed shared goal to justify colonisation into a more complex range of attempts to understand human history. It is out of this disambiguated space that it becomes possible to discern the originally intended goals of science, and to gain a deeper, more meaningful understanding of the ways those ideas have been used to shape British and Australian history writing and identities.

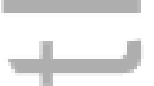

\section{REFERENCES}

\section{Archival sources:}

Correspondence between Joseph Paxton Moir and E. B. Tylor, 1898-1905, Westlake Papers (WC), Manuscript Collections (MC), Pitt Rivers Museum, (PRM). All the references to the WP, MC, PRM can be accessed digitally at: TAYLOR, R., with M. 
Jones, and G. McCarthy. Stories in Stone: an annotated history and guide to the collections and papers of Ernest Westlake (1855-1922). The University of Melbourne eScholarship Research Centre and the Pitt Rivers Museum, Oxford with the Oxford University Museum of Natural History. http://www.westlakehistory.info.

E. B Tylor Correspondence S-Y and Miscellaneous, Tylor Papers (TP), Manuscript Collections (MC), Pitt Rivers Museum, (PRM).

Correspondence to Charles Read, and Outletters, Department of Prehistory and Europe (DPE), British Museum, (BM), 1901-1905.

Correspondence to James Backhouse Walker from Henry Ling Roth, 1891-1899, W9_C19_1 to W9_C19_38, University of Tasmania Library Special and Rare Materials Collection, Australia (UTAS). http://eprints.utas.edu.au/17250/. Accessed 10 July 2015.

Correspondence to James Backhouse Walker from Joseph Paxton Moir, 1898, w9_c4_1(28)(1) and w9_c4_1(47)(1). University of Tasmania Library Special and Rare Materials Collection, Australia (UTAS). http://eprints.UTAS.edu.au/3276/. Accessed 7 July 2015 .

Henry Ling Roth, Aborigines of Tasmania, 1919. List of Papers, Printed Pamphlets, Original MSS, Letters, Photographs, Drawings, Watercolours, Books, Prints, Stone Implements, Casts of Stone Implements, etc. relating to the above. I-XLI, Manchester Museum (MM). Referenced from this archive: XIII Jas. B Walker, XVI Various MSS; XIX 12 Letters from J. W. Beattie 1893-1897 (XIX JWB, MM); XX 32 Letters From James Backhouse Walker 1891-1899 (XX JBW, MM).

\section{Secondary published sources:}

BALFOUR, H. 1925. The Status of the Tasmanians Among the Stone-Age Peoples. Proceedings of the Prehistoric Society of East Anglia 5, 1: 1-15.

BALFOUR, H. 1929. Stone Implements of the Tasmanians and the Culture-Status Which They Suggest. Hobart, Australasian Association for the Advancement of Science: $314-322$.

BARNARD DAVIS, J. 1874. On the Ostelogy and Peculiarities of the Tasmanians. Haarlem: De Erven Loosjes.

BARNARD, J. 1889. Notes on the last living Aboriginal of Tasmania. Papers \& Proceedings of the Royal Society of Tasmania: 60-64.

BICKFORD, A. 1979. Superb Documentary or Racist Fantasy? Filmnews January: 14. BOWDLER, S. 1980. Fish and Culture, a Tasmanian Polemic. Mankind 12, no. 4: 334-340. 
BONWICK, J. 1870. The Last of the Tasmanians Or the Black War of Van Diemen's Land. London, Sampson Low, Son \& Marston.

BONWICK, J. 1884. The Lost Tasmanian Race. London, Sampson Low, Marston, Searle and Rivington.

CAMERON, P. Grease and Ochre the Blending of Two Cultures at the Colonial Sea Frontier. Launceston, Fullers Bookshop, 2011.

CROZET, J. M. 1891. Crozet's Voyage To Tasmania, New Zealand and the Ladrone Islands and the Philippines in the Years 1771-1772, translated by H. Roth. London: Truslove and Shirley.

DANIEL, G. E. 1952. A Hundred Years of Archaeology. London: Gerald Duckworth.

DARWIN, C. 1871. The Descent of Man Selection And Selection in Relation to Sex. London, Murray.

DENNIS. R. M. 1995. Social Darwinism, Scientific Racism, and the Metaphysics of Race. The Journal of Negro Education, 64, 3: 243-252.

EDGEWORTH DAVID, T. W. 1923. Geological Evidence of the Antiquity of Man in the Commonwealth, With Special Reference to the Tasmanian Aborigines', Papers and Proceedings of the Royal Society of Tasmania: 109-50.

FELTON, H. 2012. Writing Tasmanian History: The Case of James Backhouse Walker. Tasmanian Historical Studies, 17: 1-44.

FFORDE, C. and HUBERT, J. 2006. Indigenous Human remains and changing museum ideology. A Future of Archaeology, eds. Robert Layton, Stephen Shennan and Peter Stone, London, UCL Press: 83-96.

FLOWER, W. H. 1877-1879. The Aborigines of Tasmania an Extinct Race. Science Lectures Delivered in Manchester. Manchester, John Heywood, Series 9 and 10.

GOUGH. J. 2014. Forgotten lives - the first photographs of Tasmanian Aboriginal people. Calling the Shots: Aboriginal Photographies, ed. Jane Lydon, Canberra: Aboriginal Studies Press: 21-54.

GRAYSON, D. K. 1986. Eoliths, Archaeological Ambiguity, and the Generation of 'Middle-Range' Research. American Archaeology Past and Future, eds. David J. Meltzer, Don. D. Fowler and Jeremy A. Sabloff, Washington: published for the Society of American Archaeology by the Smithsonian Institution Press: 77-133.

GRIFFITHS, T. 1996. Hunters and Collectors: The Antiquarian Imagination in Australia. Cambridge, England ad New York: Cambridge University Press.

HARPER, W. R. and CLARKE, A. H. 1897. Notes on the measurements of the Tasmanian crania in the Tasmanian Museum, Hobart. Papers \& Proceedings of the Royal Society of Tasmania: 97-107. 
HORTON, D. 1979. Tasmanian Adaptation. Mankind 12, 1: 28-34.

HOWITT, A. 1898. On the Origin of the Aborigines of Tasmania and Australia. Australasian Association for the Advancement of Science 7: 723-758.

HUXLEY, T. H. 1870. On the Geographical Distribution of the Chief Modifications of Mankind', The Journal of the Ethnographical Society of London 2, 4: 404-412.

JONES, R. 1971. Rocky Cape and the Problem of the Tasmanian Aborigines. PhD Thesis, University of Sydney.

JONES, R. 1977. 'The Tasmanian Paradox' in Stone Tools as Cultural Markers, ed. R. V. S. Wright. Canberra: Australian Institute of Aboriginal Studies: 189-204.

JONES, R. 1978. Why Did the Tasmanians Stop Eating Fish? Explorations in Ethnoarchaeology, ed. R. A. Gould. Albuquerque: University of New Mexico Press: $11-47$.

JONES, R. 1990. From Kakadu to Kutikina: the southern continent at 18 ooo years ago. The World at 18 ooo BP, Volume Two, Low Latitutes, eds. Clive Gamble and Olga Soffer. London: Unwin Hyman: 264-295.

JONES, R. 1995. Tasmanian Archaeology: Establishing the Sequences. Annual Review of Anthropology 24: 423-446.

JONES, R. and MEEHAN, B. 2000. A Crucible of Australian prehistory: The 1965 ANZAAS Conference. Australian Archaeologist: Collected Papers in Honour of Jim Allen, eds. Atholl Anderson and Tim Murray, Canberra: Coombs Academic Publishing: 40-61.

KEEN I. 2000. The Anthropologist as Geologist: Howitt in Colonial Gippsland. The Australian Journal of Anthropology, 11, 1: 78-97.

LANGFORD, R. F. 1983. Our Heritage - Your Playground. Australian Archaeology 16: 1-6.

LAWSON, T. 2014. The Last Man: A British Genocide in Tasmania, London, I. B. Taurus.

LUBBOCK, J.1865. Pre-historic Times, as Illustrated by Ancient Remains, and the Manners and Customs of Modern Savages. London: Williams and Norgate.

MACDONALD, H. 2005. Human Remains: Episodes in Human Dissection. Melbourne: Melbourne University Press.

MCDOUGALL, R. 2007. Henry Ling Roth in Tasmania. Writing, Travel and Empire: In the Margins of Anthropology eds. Peter Hulme and Russell McDougall. London and New York: IB Taurus: 42-68. 
MCGREGOR. R. 1997. Imagined Destinies: Aboriginal Australians and the Doomed Race Theory, 1880-1939, Melbourne, Melbourne University Press

MCNIVEN, I. and Russell, L. 2005. Appropriated Pasts: Indigenous Peoples and the Colonial Culture of Archaeology. Oxford: AltaMira.

MANSELL, M. 1978. 'The Last Tasmanian', Racism in Tasmania. Sydney: National Union of Students pamphlet. Also published as MANSELL, M. 1978. Black

Tasmanians Now. Arena 51: 5-8.

=

MULVANEY, J. 1990 (1961). The Stone Age of Australia. Prehistory and Heritage, The Writings of John Mulvaney, ed. Janine Mummery. Canberra: The Australian National University, 1990: 16-54. First published in 1961. The Prehistoric Society 4: 56-107.

MULVANEY, J. 2001. Peopled Landscapes: From Prehistoric Tasmania to Contemporary Arnhem Land. Histories of Old Ages: Essays in Honour of Rhys Jones, eds. Atholl Anderson, Ian Lilley and Sue O’Connor. Canberra: Pandanus Books: $19-22$.

MURRAY, T. 1992. Tasmania and the Constitution of 'the dawn of humanity. Antiquity 66, 252, Sept: 730-743.

PETCH, A. Tylor and Technology, 'The Other Within' project: http://england.prm.ox.ac.uk/englishness-Tylor-and-technology.html. Accessed 7 July 2015

PETROW, S. 1998. The Last man: The Mutilation of William Lanne in 1869 and its Aftermath. Australian Cultural History, 16: 18-44.

PULLEINE, R. 1928. The Tasmanians and Their Stone-Culture. Australasian Association for the Advancement of Science 19: 294-314.

ROE, D. 1981. Amateurs and archaeologists: some early contributions to British Palaeolithic studies. Antiquity and man, essays in honour of Glyn Daniels, J.D. Evans, B. Cunliffe and C. Renfrew (eds). London: Thames \& Hudson: 214-220.

ROTH, H. LING. 1889. A Surviving Tasmanian Aborigine. Nature, 41, 5 December 1889: 105 .

ROTH, H. LING. 1890. The Aborigines of Tasmania. London: Kegan Paul, Trench, Trüber \& Co.

ROTH, H. LING. 1899. The Aborigines of Tasmania. Halifax, England: F. King \& Sons.

RYAN, L. 1985. Extinction Theorists and Tasmanian Aborigines: Apologists for an Extermination Policy. The Future of Former Foragers in Australia and Southern Africa, eds. Carmel Schrire and Robert Gordon. Cambridge, MA: Cultural Survival Inc.: $47-54$. 
RYAN, L. 1996. The Aboriginal Tasmanians. Sydney: Allen and Unwin, 1996, 2nd edition.

RYAN, L. 1997. The Struggle for Trukanini 1830-1997. Peter Eldershaw Memorial Lecture Tasmanian Historical Research Association Papers and Proceedings 44, 3: $153-173$

RYAN, L. 2012. Tasmanian Aborigines: A History Since 1803. Sydney: Allen and Unwin.

SACKETT, J. 2014. Boucher de Perthes and the Discovery of Human Antiquity. Bulletin of the History of Archaeology, 24, 2: 1-11, DOI:

http://dx.doi.org/10.5334/bha.242

SMITH. N. 1976. Walker, James Backhouse (1841-1899). Australian Dictionary of Biography, National Centre of Biography, Australian National University, http://adb.anu.edu.au/biography/walker-james-backhouse-4786/text7969, published first in hardcopy 1976, accessed online 26 February 2016.

SOLLAS. WJ. 1911. Ancient Hunters and Their Modern Representatives. London, Macmillan.

TAYLOR, R. 2008. The Polemics of Making Fire: the historical evidence revisited. Aboriginal History, 32, 2008: 1-26.

TAYLOR, R. 2012. The National Confessional. Meanjin Quarterly, 3: 22-36.

TAYLOR, R. 2013. Genocide, Extinction and Aboriginal Self-determination in Tasmanian Historiography. History Compass. 11, 6: 405-419.

TAYLOR, R with M. Jones and G. McCarthy. 2013. See above note on archives.

TAYLOR, R. 2014. Australian Archaeology and Aboriginal Protest: how politics and poetry of Rhys Jones' Tasmanian work changed Australian historiography.

Australian Historical Studies 45, 2: 331-349.

TINDALE, N. B. 1937-41. Relationship of the Extinct Kangaroo Island Culture with Cultures of Australia Tasmania and Malaya', Records of the South Australian Museum, VI: 39-59.

TYLOR, E. B. 1871. Primitive Culture. London: John Murray.

TYLOR, E. B. 1890. Preface. Roth, H. Ling, The Aborigines of Tasmania. London: Kegan Paul, Trench, Trüber \& Co: v-viii.

TYLOR, E. B. 1894. On the Tasmanians as Representatives of Palaeolithic Man. Journal of the Royal Anthropological Institute of Britain and Ireland 23: 141-152. 
TYLOR, E. B. 1895. On the Occurrence of Ground Stone Implements of Australian Type in Tasmania, Journal of the Royal Anthropological Institute of Britain and Ireland, 24: 335-340.

TYLOR, E. B. 1898. On the Survival of Palaeolithic Conditions in Tasmania and Australia. Journal of the Royal Anthropological Institute of Britain and Ireland, 23: $141-152$

TYLOR, E. B. 1899. Preface. Roth, H. Ling, The Aborigines of Tasmania. Halifax, England: F. King \& Sons: vii-ix.

TYLOR, E. B. 1900. On Stone Implements from Tasmania: Extracts from a Letter by J. Paxton Moir. The Journal of the Royal Anthropological Institute of Great Britain and Ireland, 31: 257-259.

TYLOR, E. B. 1900. On the Stone Age in Tasmania, as Related to the History of Civilisation. Journal of the Royal Anthropological Institute, 30: 33-34.

TYLOR, E. B. 1964. Researches into the Early History of Mankind, ed. Paul Bohannan. Chicago and London: University of Chicago Press. (Republished from the 3rd edition, 1878).

TYLOR, E. B. 1994. The Collected Works of Edward Burnett Tylor with a new introduction by George Stocking. London: Routledge \& Thoemmes.

WALKER, G. W. and Walker, J. B. 1897. Notes on the aborigines of Tasmania, extracted from the manuscript journals of George Washington Walker, with an introduction by Walker, James B. Papers \& Proceedings of the Royal Society of Tasmania: 145-175. University of Tasmania ePrints: http://eprints.utas.edu.au/16183/. Accessed 10 July 2015.

WALKER, BACKHOUSE J. 1900. The Tasmanian Aborigines. Hobart: John Vail Government Printer.

WHITE, J. P. with O'Connell, J. F. 1982. A Prehistory of Australia, New Guinea and Sahul. Sydney: Sydney Academic Press.

WINDSCHUTTLE, K. 2002. The Fabrication of Aboriginal History, Volume One, Van Diemen's Land 1803-1847. Sydney: Macleay Press.

WOOD JONES, F. 1935. Tasmania's Vanished Race. Sydney [?]: Australian Broadcasting Commission.

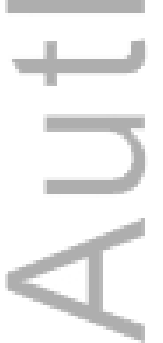


${ }^{1}$ Moir to Tylor, 23 January 1899, WP, MC, PRM, ff. 36-36v: Image 9, WESTooo18, Stories in Stone:

http://www.westlakehistory.info/viewer/WEST/item/WESTo0018/9. Accessed 10 July 2015.

2 Tylor, 'Growth and Spread of Culture', TP, MC, PRM.

3 Roth to Walker, 18 October 1891, W9C19_1, UTAS.

4 Petch, Alison: Tylor and Technology, 'The Other Within' project: http://england.prm.ox.ac.uk/englishness-Tylor-and-technology.html. Accessed 7 July 2015.

5 WL Williamson to EB Tylor from, 6 August 1893 to 16 July 1897, WP, PRM; WL Williamson to EB Tylor, 16 October 1897 and FF Tuckett to EB Tylor 13 February 1895, Tylor Papers, Correspondence S-Y and Miscellaneous, PRM.

${ }^{6}$ These holdings were confirmed by correspondence and archival research I carried out in England from 2008-2009. I am grateful for the support of those institutions in making accessible information from their catalogues and archives.

7 Wilkinson donated more than 50 implements to the British Museum in 1901. Wilkinson to Read, 18 April 1901 DPE, BM; Read to Wilkinson, 30 May 1901, DPE, Outletters 1901, BM.

8 Moir to Walker, 11 January 1898 w9_c4_1(47)(1), UTAS. Moir explains to Walker that he has written to Johnston and Morton as well.

9 Moir to Walker, 11 January 1898 w9_c4_1(47)(1), UTAS. Moir explains to Walker that he has written to Johnston and Morton as well.

${ }^{10}$ Moir to Walker, 11 January 1898, w9_c4_1(28)(1), UTAS.

${ }^{11}$ Moir to Tylor, 23 January 1899, WP, MC, PRM, ff. 36-36v. Image 9, WESTo0018: Stories in Stone:

http://www.westlakehistory.info/viewer/WEST/item/WESTooo18/9.

${ }^{12}$ Moir to Tylor, 12 May 1905, WP, MC, PRM, f79v. Image 38, WESTooo19: Stories in Stone:

http://www.westlakehistory.info/viewer/WEST/item/WESToo019/38. Accessed 10 July 2015. 
${ }_{13}$ Moir to Tylor, 21 March 1899, WP, MC, PRM, f. 45; Image 22, WESTooo18: Stories in Stone:

http://www.westlakehistory.info/viewer/WEST/item/WESTooo18/22. Accessed 10 July 2015.

${ }^{14}$ Moir to Tylor, 26 November 1900, WP, MC, PRM, f. 66v; Image 14, WESToo019, Stories in Stone:

http://www.westlakehistory.info/viewer/WEST/item/WESTooo19/14. Accessed 10 July 2015 .

${ }_{15}$ Moir to Tylor, 27 October 1900, WP, MC, PRM, ff. 58, 62; Image 5, WESTO0019: Stories in Stone:

http://www.westlakehistory.info/viewer/WEST/item/WESTooo19/5 and Image 9, WESToo01 www.westlakehistory.info/viewer/WEST/item/WESTo0019/9; Moir to Tylor, 26 November 1900, WP, MC, PRM, f. 67; Image 14, WESTooo19, Stories in Stone: http://www.westlakehistory.info/viewer/WEST/item/WESTooo19/14. Accessed 10 July 2015.

${ }^{16}$ Moir to Tylor, 23 January 1899, WP, MC, PRM, ff. 36-36v. Image 9, WESTO0018: Stories in Stone:

http://www.westlakehistory.info/viewer/WEST/item/WESToo018/9 and Image 10, WESTo0018: Stories in Stone http://www.westlakehistory.info/viewer/WEST/item/WESTooo18/10. Accessed 10 July 2015

17 Walker to Roth, 16 May 1898, XX JB W, MM.

${ }_{18}$ Moir to Tylor, 14 May 1905, WP, MC, PRM, f. 81v; Image 42, WESTooo19: Stories in Stone:

http://www.westlakehistory.info/viewer/WEST/item/WESTooo19/42. Accessed 10 July 2015.

${ }_{19}$ Roth to Tylor, 13 February 1899, WP, MC, PRM, f. 41; Image 18, WESTooo18: Stories in Stone:

http://www.westlakehistory.info/viewer/WEST/item/WESTooo18/18. Accessed 10 July 2015 .

${ }^{20}$ Tylor to Roth, 26 February 1899, 27 February 1899, 1 March 1899, XVI 'Various MSS', MM 
${ }^{21}$ Roth to Walker, 30 May 1899, W9C19_32, UTAS.

${ }^{22}$ Moir to Tylor, 12 May 1905, WP, MC, PRM, f. 8ov. Image 40, WESTooo19: Stories in Stone:

http://www.westlakehistory.info/viewer/WEST/item/WESTooo19/40. Accessed 10 July 2015.

23 Pitt Rivers to Tylor, 7 August 1898, TP, MC, PRM.

${ }^{24}$ Stocking writes that Tylor's last book was based on the Gifford Lectures he presented in 1889 and 1890 and was to be published in 1907: Tylor 1994: xxiii-xxiv) Stocking refers to printed galleys of some of the book's chapters. I have only seen rough drafts in boxes 5 and $10 \mathrm{TP}, \mathrm{MC}, \mathrm{PRM}$. According to a letter to Moir it was to be Growth and Spread of Culture; draft letter Tylor to Moir 25 July 1905, WP, MC, PRM, f. 83v; Image 3, WESTooo20: Stories in Stone:

http://www.westlakehistory.info/viewer/WEST/item/WESTooo20/3. Accessed 10 July 2015.

25 Tylor, 'Growth and Spread of Culture', TP, MC, PRM.

${ }^{26}$ St George Gray to Read, 29 April 1905, DPE, BM.

${ }_{27}$ Roth to Walker, 18 October 1891,W9C19_1, UTAS.

${ }^{28}$ Walker to Roth, 20 December 1891, XX JBW, MM.

29 Walker to Roth. 12 March 1893, 30 September 1893, XX JBW, MM.

${ }^{30}$ XIII Jas. B. Walker, MM.

${ }^{31}$ Roth to Walker, 13 April 1898, W9C19_27 UTAS.

32 Walker to Roth, 15 June 1895, XX JBW, MM.

33 JB Walker's Remarks on Bonwick's Daily Life of the Tasmanians. Notes respecting writers on the Aborigines of Tasmania, XVII 'Various MSS', MM.

34 Walker to Roth, 30 January 1897, 24 April 1897, 3 October 1897, 20 May 1898, XX JBW, MM.

35 Roth to Walker, 15 August 1897, W9C19_18, UTAS.

${ }_{36}$ Walker to Roth, 20 May 1898, XX JBW, MM.

37 Walker to Roth, 24 April 1897, 17 October 1897, 1 November 1897, 26 December 1897, XX JBW, MM; Quaker Life in Tasmania, Quaker Biographies, Francis Cotton: 
http://www.utas.edu.au/library/exhibitions/quaker/quaker biographies/quaker bi og f cotton.html. Accessed 5 August 2015.

${ }^{38}$ Walker tô Roth, 20 May 1898, XX JBW, MM.

39 Walker to Roth, 24 April 1897, XX JBW, MM.

${ }^{40}$ Roth to Walker, 4 August 1898, W9C19_29, UTAS; Walker to Roth, 20 May 1898, 11 June 1898, XX JBW, MM.

${ }^{41}$ Walker to Roth 15 June 1895, XX JBW, MM.; Roth to Walker, 3 August 1898, W9C19_6, UTAS.

${ }^{42}$ Walker to Roth, 3 October 1897, 20 May 1898, XX JBW, MM.

43 Roth to Walker, 13 April 1898, W9C19_27, UTAS.

44 Walker to Roth, 3 October 1897, 12 December 1897, XX, MM.; Roth to Walker, 23 September 1898, W9C19_31, UTAS.

45 Beattie to Roth, 22 September 1893, XIX JWB, MM.

${ }^{46}$ Walker to Roth, 30 January 1897, XX JBW, MM.

47 Roth to Walker, 6 May 1897, W9C19_15, UTAS.

${ }^{48}$ Walker to Roth, 3 October 1897, XX JB,W, MM.

49 Walker to Roth, 10 June 1896, 20 May 1898 and 16 May 1899, XX JBW, MM.

Rayner to Walker (copied by Walker for Roth) 20 April 1898, XXVV, MM.

${ }^{50}$ Walker to Roth, 24 April 1897, XX JBW, MM; Walker and Walker, 'Notes on the aborigines of Tasmania'.

${ }^{11}$ Walker to Roth, 21 March 1894, 30 Jan 1897, 24 April 1897, 17 October 1897, 20 November 1897, 9 October 1898, 16 May 1899 XX JBW, MM.

${ }^{2}$ Beattie to Roth, 12 March 1897, XIX JWB, MM., Walker to Roth, 14 and 27 March 1897, XX, MM., Roth to Walker, 6 May 1897, W9C19_15, UTAS.

53 Walker to Roth. 12 March 1893, 30 September 1893, XX JBW, MM.

${ }^{54}$ Beattie to Roth, 23 September 1893, XIX JWB, MM.

55 Beattie to Roth, 3 March 1894, XIX JWB, MM.

${ }^{56}$ Beattie to Roth, 12 October 1894, XIX JWB, MM.

57 Roth to Walker, 3 August 1895, W9/C1/9_14, UTAS.

${ }_{58}^{8}$ Beattie to Roth, 2 November 1896, XIX JWB, MM. 
59 Holden to Beattie, 3 January 1897, XVI 'Various MSS' (mistakenly dated as 1896 by Holden, but sent promptly after receipt by Beattie to Roth: 11 January 1897, XIX JWB, MM)

${ }^{60}$ Geeves to Beattie, 21 October 1896, forwarded to Roth, XIX JWB, MM.

${ }^{61}$ Geeves to Beattie, 21 October 1896, forwarded to Roth, XIX JWB, MM.

${ }^{62}$ Beattie to Roth, 10 July 1897 (see also 27 February 1897), XIX JWB, MM.

${ }^{63}$ Beattie to Roth, 4 December 1897, XIX JWB, MM.

${ }^{64}$ Beattie to Roth, 27 February 1897, XIX JWB, MM., Walker to Roth, 12 December 1897, XX, MM., Roth to Walker, 14 April? 1898, W9C19_25, UTAS.

65 Roth, The Tasmanian Aborigines, 1899, p. 1xxxiv.

${ }^{66}$ Roth to Walker, 14 April? 1898, W9C19_25, UTAS.

67 Walker to Roth, 14 March 1897, XX JBW, MM.

68 Walker to Roth, 30 September 1893, XX, MM; Roth to Walker, 3 August 1895, W9C19_6, UTAS; Walker to Roth, 24 September 1899, XX JBW, MM.

68 Tylor to Roth, 14 February 1899, XVI 'Various MSS', MM.

69 Walker to Roth, 14 August 1899, XX, MM.

${ }^{70}$ Walker to Roth, 14 August 1899, XX JBW, MM.

${ }^{71}$ For a more extended version of some of the ideas set out in this epilogue see Taylor 2014 .

${ }^{2}$ Ronin Films, 'The Last Tasmanian Study Guide': www.roninfilms.com.au/get/files/987.pdf. Accessed 24 July 2015.

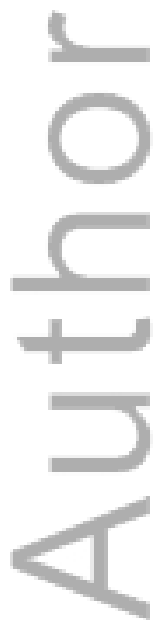


The First Stone and the Last Tasmanian: The Colonial Correspondence of Edward Burnett Tylor and Henry Ling Roth.

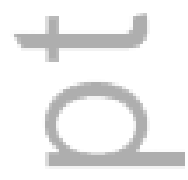

$=$

(10)
Rebe Taylor

University of Melbourne

ABSTRACT

Between 1890 and 1905, Edward Burnett Tylor and Henry Ling Roth extended and formalised two ideas that were intricately connected and deeply influential to the development of nineteenth century anthropology: that the Tasmanian Aboriginal people represented the earliest phase of cultural evolution and that they were extinct. This paper offers a detailed archival exploration of the correspondence between 18911905 that informed those ideas. It finds that Tylor and Roth not only received abstracted facts and artefacts from their colonial contacts; they were directed and inspired by an emergent Australian scholarship that sought to propose and urge new disciplinary directions. This paper reveals not only the importance of Tasmanian Aboriginal people to the history of science, but the role that scientific ideas have shaped Australian social memory and national identity.

Keywords: Tasmania, Aborigines, Tylor, Ling Roth, Australia

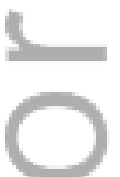

\section{INTRODUCTION}

If Aboriginal Australians were essential subjects in the development of the theories of evolutionism because of their 'primitivism', Tasmanian Aboriginal people held a special significance. They were deemed to be one of the most isolated and unique races in the world, and also the most primitive, 'lower' even than the Aboriginal peoples of mainland Australia. Tasmanian Aboriginal material culture was believed by early theorists to equate to the recently discovered European 'Stone Age'. Thus they represented a 'survival' from a very distant past. They were also the only 'race' colonised by the British to become 'extinct'. From the 1830 , when the colonial frontier Black War was ending, the Tasmanian Aboriginal peoples' extinction was deemed inevitable; it was declared final with the passing of Truganini in 1876, as the supposed last 'full blood' of her 'race'. The combined discourses of the 'extreme 
primitivism' and 'extinction' of the Tasmanians came to demonstrate the progressive laws of human evolutionary theory. Charles Darwin observed in 1871 that the Tasmanians' demise was a 'natural' consequence of 'when civilised nations come into contact with barbarians' (Darwin 1871: 238). This logic and justification for colonial conquest became, therefore, intrinsic to the shaping of British racial superiority. Historian Tom Lawson reflects that the supposed extinction of the Tasmanian Aboriginal peoplees was not merely an 'important part of an identity in which Britain was imagined to be at the apex of human progress', it 'relied' upon it. Even the widely voiced regret over their passing was often 'tinged with pride' over the demonstrated 'might' of the Empire (Lawson 2014: 162, 171). This regret reemerged in late twentieth century Australia as a collective sense of national shame. But the reiteration of extinction offered contrition without recompense and denied a contemporary Tasmanian Aboriginal community recognition of their existence and rights.

This article offers the first detailed historical exploration of the development of the ideas of extreme primitivism and the extinction of Tasmanian Aboriginal people. It identifies two major exponents: Edward Burnett Tylor, the founder of British anthropology, who originated the theory of the Tasmanian Aboriginal peoples' 'extreme primitivism' based largely upon the study of just one stone tool, the famous 'Taunton Scraper' in about 1860; and Henry Ling Roth, a gentleman anthropologist and English businessman, who sought to verify which Tasmanian Aboriginal person was the last 'fullblood' . Their projects were founded on gross misjudgments and misuse of Tasmanian Aboriginal peoples' culture and bodies but both men were regarded as the leading authorities on the topic. Tylor's 1894 paper, 'On The Tasmanians as Representatives of Paleolithic Man' was widely referenced and seen as fundamentally influential to the understandings of human origins and cultural development. Roth's The Tasmanian Aborigines-The Aborigines of Tasmania (1890) was the first anthropological book on the subject. The second edition, published in 1899, remained the most referenced text on the subject, reiterating the 'fact' of extinction, until the mid-196os.

This article reveals how Tylor and Roth's authority relied heavily upon the knowledge and guidance offered to them by informants living in Tasmania: keen amateur scholars and collectors, among them published writers with expert knowledge of the Aboriginal history and collections. An examination of this extensive correspondence also brings into question the seeming collusive logic of Tylor's theory of 'extreme primitivism' and Roth's confirmation of extinction. While they accepted each other's premises, Tylor's goal to discover the representative beginning of 
cultural evolution, and Roth's first imperative to verify who was the 'last' Tasmanian, were distinct ambitions with different methodologies and requirements.

This archival exploration offers a second realisation: Roth and Tylor's correspondence with settler Tasmanians does not model a classical split between colony and metropole. It was carried out on the eve of Federation in 1901, and in Tylor's case, continued for some years after. The letters from Tasmania reveal an emergent Australian scholarship that was finding its own direction, capability and recognised centres of expertise. The writers understood their role as directing and influencing the British scholars whom they assumed knew less about 'their' local Aborigines.

These realisations and their implications are explored in this article across two major parts and an epilogue. 'The First Stone' examines Tylor's interest in the Tasmanian Aboriginal people from 1860 to 1905. It begins with his famous encounter with the 'Taunton Scraper' in 1860 (Griffiths 1996: 53; Murray 1992; Mulvaney 1990: 45; McNiven and Russell 2005: 64-66), and then enriches these accounts with further detail, including the association between Tylor and Roth. Helen Macdonald's astute observation that Tylor's 1894 paper intersected and extended the significant and longstanding debate between the theories of monogeny and polygeny is extended to reveal how Tylor's work inspired the worldwide collection and study of Tasmanian stone artefacts as a way to understand human cultural history. The article also offers the first exploration of an extensive correspondence between Tylor and a local collector, Joseph Paxton Moir between 1898-1906. Moir challenged Tylor's theory of the Tasmanians as early 'Palaeolithic', arguing their stone culture showed diversity and skill, an idea that foreshadowed how leading scholars interpreted Tasmanian stone culture in the twentieth century (Balfour 1925; Mulvaney 1990).

The paper's second section, ‘The Last Tasmanian', explores Roth's correspondence with Tasmanian local scholars between 1891 and 1899, foremost with Hobart-born barrister and local historian, James Backhouse Walker. Roth instigated the correspondence after reading that Mrs Fanny Smith (nee Cochrane) was a 'full-blood' Tasmanian Aboriginal (Barnard 1889). The request to verify this claim inspired an eight-year correspondence with Walker that resulted in a much-altered second edition of The Tasmanian Aborigines - The Aborigines of Tasmania in 1899. This exchange has been explored in some detail (Felton 2012 and McDougall 2007), but this paper offers a more expansive account that places it in context with coeval work of Tylor and Moir and also includes Roth's correspondence with Tasmanian photographer, J. W. Beattie. 
Further, this paper brings to light how Walker sat at the centre of what Moir described as a 'circle or clique' of scholars who dominated the study of Tasmanian Aboriginal history and culture. ${ }^{1}$ Hobart was their own metropole from which they gathered and filtered anthropological ideas they collected from around the colony, then state, largely through their own correspondence, and then disseminated it onto Britain. The Hobart 'circle' operated in parallel to what Tom Griffiths identifies as Victoria's 'stone circle' of amateur anthropologists clustered at this time around Melbourne's Professor Baldwin Spencer who dominated the interpretation and collection of Aboriginal artefacts and culture in that colony. While Spencer formed his ideas in 'dialogue with European theorists', his circle also 'turned their backs on them'. They were openly 'suspicious' of 'armchair theorists', promoting fieldwork and collecting, as the only way to understand and interpret Aboriginal culture (Griffiths 1996: 67, 70, 78).

While Walker and his circle rarely left Hobart, and while they also deferred many of their ideas and findings to Britain, like the Victorian circle, the Hobart scholars were conservative in their interpretations. Both groups accepted that the Aborigines represented a 'low' level of human cultural evolution, with little history of change, and as such their findings supported the persistence of evolutionary understandings of Aboriginal cultures.

It was the scholars who sat at the margins of the Hobart and Melbourne circles whose ideas challenged most vigorously those of the metropole, and in turn foreshadowed some of the key developments in Australian anthropology and archaeology. This is evident in Moir's unusual ideas about the variation and skill of Tasmanian stonework. An important corresponding example found in the work of anthropologist, magistrate and co-author of Kamilaroi and Kurnai Alfred W. Howitt. In 1898, Howitt contended that the Tasmanian Aboriginal people had reached their island by foot before rising seas at the end of the Pleistocene (around 12,00o years ago) created the Bass Strait (Griffiths 1996: 62-63). Howitt was in communication with, but not part of, Spencer's inner circle, which remained sceptical of Aboriginal antiquity well into the twentieth century. But the question of the Tasmanians' origins and possible antiquity became one of the founding debates of Australian archaeology. By 1961, under the leadership of archaeologist John Mulvaney, the question of Tasmania's antiquity was central to the discipline's wider goal to determine the depth of the continent's human occupation (Mulvaney 1990: 15).

In an epilogue this paper explains the importance of Roth's and Tylor's correspondence to understanding the ideas and discoveries of twentieth century Tasmanian archaeology. In 1965 archaeologist Rhys Jones surmised that Howitt had 
been right: the first Tasmanians had reached their country across a dry Bassian plain (Jones and Meehan 2000: 40). But Jones stirred controversy when he suggested that the Tasmanian Aboriginal people had suffered an isolation-induced regression and even if colonisation had never occurred that they may nonetheless have been | 'doomed' to extinction. (Jones 1977: 197, 202-203). The Aboriginal and academic communities accused Jones of reiterating nineteenth-century evolutionary theory. (Bickford 1979: 14, Bowdler 1980: 335, Ryan 1985 and 2012: xix-xx). In fact Jones was a passionate anti-colonialist, and his scientific ideas were more closely connected to Howitt than to Tylor, for he had sought to realise the depth and change within Aboriginal history.

Finally, this paper concludes that to understand the difference between Jones' and Tylor's research goals it is necessary to first recognise the distinctions between Tylor's and Roth's interests in the Tasmanian Aboriginal peoples' 'primitivism' and 'extinction'. For only then does it become possible to elucidate the ways an emergent colonial scholarship did more than underpin those scholars' ideas, it also proposed and urged new disciplinary directions.

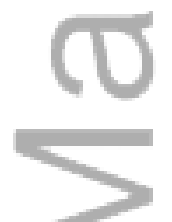

\section{THE FIRST STONE}

In 1860 Edward Burnett Tylor was at the beginning of a career that would establish the discipline of social anthropology as a science. In that year he attended a meeting of the Somerset Archaeological Society in Taunton where Mr Thomas Dawson presented a small stone implement from Tasmania. Tylor noted how the tool was chipped roughly, but effectively, on one side creating a sharp edge for scraping (Tylor 1890: v-vi). He was struck by the tool's apparent similarity with the European artefacts found in the Somme river gravels that only months earlier had been confirmed as dating back to the last Ice Age, or Pleistocene (Sackett 2014: 1). The comparison was a revelation. As Tylor later put it: 'Man of the Lower Stone Age ceases to be a creature of philosophic inference, but becomes a reality' (Tylor 1899: ix). The European Stone Age was both remote in time, and yet an object of recent discovery. The 'Taunton Scraper', as the small Tasmanian tool came to be famously known ${ }_{2}$ encapsulated the deep past for Tylor; it was as if he could hold the beginning of human culture in the palm of his hand. The single tool continued to play an inspiring role throughout Tylor's lifework, shaping fundamentally his theories of cultural evolutionism. The reverse was also true; the ways Tylor presented and 
interpreted the Taunton Scraper developed in accordance with his wider thinking and experience earned through researching the Tasmanian artefacts more thoroughly, and his wider studies into world cultures.

In 1862, Tylor attended the Great Exhibition in London and met Joseph Milligan, Commissioner for Tasmania, and former superintendent of the Oyster Cove Aboriginal Station, south of Hobart. Tylor asked Milligan if he thought the Taunton Scraperwas typical in its manufacture. Milligan explained to him, he later quoted, that the Aborigines would 'pick up a suitable flat stone, knock off chips from one side, partly or all round the edge, and use it without more ado' (Tylor 1890: vi). So it was that in his 1865 book, Researches into the Early History of Mankind Tylor wrote that: 'the Natives of Van Diemen's Land, whose dismal history is ending in total extinction, are the lowest tribes known to ethnology' (Tylor 1964: 195). It was perhaps with Tylor's influence that in the same year British archaeologist, John Lubbock also made a comparison between the 'Van Diemener' (Tasmanian Aboriginal person) and the Stone Age culture, to which he gave the name the 'Paleaolithic' (Lubbock 1865: 336-337).

Tylor did not return to the subject of the Tasmanian Aboriginal culture until he wrote the Preface to Henry Ling Roth's 1890 The Aborigine of Tasmania. He explained his intense interest in the subject: while there were many extant Stone Age tribes, the Tasmanian Aboriginal people alone illuminated the earliest phase of European culture. If it seemed improbable that men of the 'Drift' (as he termed the Last Ice Age) held their axes rather than haft them, their 'ignorance' became plausible 'because it prevailed in Tasmania' (Tylor 1890: v-vii).

Tylor's interest in the Tasmanians renewed, he explored his thinking across five papers written between 1894-1900 (Tylor, 1894, 1895, 1898, 1900). The first publication, 'On The Tasmanians as Representatives of Paleolithic Man' was the most referenced. The title alone assured its impact. It reaffirmed the Tasmanians to the culture phase defined by Lubbock: the earliest phase of cultural development. Lastly, in about 1905, Tylor drafted a chapter on the cultural status of the Tasmanian Aboriginal people for his last, but unpublished book on cultural evolution. ${ }^{2}$

Since the Taunton Scraper remained almost the only Tasmanian Aboriginal stone artefact he had seen, Tylor sought to expand his collection to include a wider range of tool types. On Tylor's behalf, Roth wrote to James Backhouse Walker, in 1891: 'we, in England, are badly in want' of Tasmanian stone implements. With the exception of 'the one stone in the Taunton ... museum' and a half dozen belonging to Pitt Rivers Museum curator, Henry Balfour, 'no one at home appears to be the possessor of any.'3 
Walker was slow in organising the stone artefacts, and Tylor followed up the request himself. He soon received 'a number' of stone implements from Alexander Morton, curator of the Royal Society of Tasmania's Museum, and a 'general collection' of about 150 implements from WL Williamson who ran a 'curios' shop in Browns River, near Hobart (Petch). 4 Tylor's brother-in-law, the renowned Mountaineer, Francis Fox Tuckett, consequently visited Williamson in 1895. He found him to be 'a well-known character' who dealt with 'shells, and ancient fish-like articles with smells to match' in a 'higgledy-piggledy museum in little shed near the beach'. Williamson required exchange for the stone tools he sent to Tylor: Roman and English coins, shells and stamps. With the hope of a more profitable swap, he offered a skull from the Aborigines' cemetery at Oyster Cove, which Tylor declined. 5

In this Tylor was distinct. Since the mid-nineteenth century, the Tasmanians' bodies had become 'rare collectables' (MacDonald 2005: 10). As extinction seemed imminent, the collection of Tasmanian human remains became urgent and competitive. Body parts were exchanged in 'favours' and deals driven as much by the desire of possession as for any scientific intention (MacDonald 2005: 10). When Hobart hospital surgeons dissected illicitly the body of William Lanne, the so-called 'last' Tasmanian Aboriginal man in 1869, it created a public outcry. It was decreed that when Truganini died, her body should be left to rest (MacDonald 2005: 136-182, Petrow 1998: 39-40). But the Royal Society applied successfully to have her remains disinterred. For the ninety-eight years her skeleton was in the museum in Hobart, little research was ever carried out on her remains (Fforde and Hubert 2006: 83-96). There were, however, two extensive anthropological studies carried out on Tasmanian human remains in Britain in the 1870s. Tylor would later challenge these studies, and in so doing extend an older debate over human origins.

On the eve of Charles Darwin's revolutionary 1859 publication The Origin of the Species, British racial scientists had been edging towards an agreement that the cause of biological human variation was multiple and distinct origins; the theory of polygeny (Griffiths 1996: 45). Darwin's theory of transmutation, however, bolstered the counter argument for single, shared human origins; monogeny. The discovery of human antiquity also in 1859 offered the expanse of time required to successfully argue that migration and slow environmental adaption was the cause for the wide geographic distribution and physical human diversity of races.

But the debate was not resolved, and it was predictable that the Tasmanian Aboriginal people should be drawn into its centre. Their isolation and supposed physical and cultural differences lead to the assumption that they were a unique race 
with distinct origins (Huxley 1870: 18; Griffiths 1996: 63). The question then remained: where had the Tasmanians come from, and when?

Anatomist Joseph Barnard Davis was possessor of one of the largest private collections of human remains from across the world, including Tasmania. In 1874, Davis argued that the only logical explanation for the Tasmanians' physical and cultural differences was a distinctive biological origin; they offered an unambiguous case for polygeny (Davis 1874). Anatomist William Flower of the British Museum answered with reference to another large collection of skeletal material that the Tasmanians' differences and 'extreme primitivism_ were the result of a slow transformation caused by a long isolation, and as such offered a clear demonstration of monogeny (Flower 1877-1879).

Tylor intersected this debate in 1894 with his paper, 'On The Tasmanians as Representatives of Paleolithic Man'. Tylor's paper was a more precise rendering of his ideas outlined in Roth's 1890 Preface, bolstered with reference to new material sent from Tasmania, but there was a significant addition. Tylor was a monogenist, but he challenged the idea that the Tasmanians' 'extreme primitivism' could be result of cultural decline caused by isolation. 'Of degeneration', Tylor wrote of Tasmania, '...there is at present no evidence' (Tylor 1894: 148). Tylor understood culture to be universal and progressive. It was that 'complex whole' of customs, beliefs and knowledge that determined membership of a society' (Tylor 1871: 1). All societies however primitive - possessed culture and with it an innate potential to evolve. For Tylor, the Tasmanians' offered a singularly significant example of that potential in its earliest phase of evolution. They represented the beginning of human culture. Tylor's 1894 paper placed his evolutionary theory squarely in the centre of the monogeny/polygeny debate (Macdonald 2005: 123-134). In so doing he inspired a shift away of the focus on Tasmania from their human remains to their remnant stone artefacts to illuminate the beginnings of cultural evolution.

By the early twentieth century most museums with an anthropological purpose in Britain, and some beyond, had at least a small number of Tasmanian Aboriginal stone implements. Many possessed far more. By sheer volume, stone tools make up the largest part of the overseas Tasmanian Aboriginal collections. Museums in Brighton, Bristol, Belfast, Cambridge, Leeds, Liverpool, London, Manchester, Oxford and Sheffield each house over a hundred Tasmanian stone tools; there are collections in Basel, Bern, Brussels, Copenhagen, Geneva, Göteborg, Leipzig, Leiden, Paris, Rome, and Stockholm; and further afield: Cape Town and Hawaii. Almost all of these collections were formed by resident Tasmanians and sent either as donations or by request. Institutional exchanges were also common, as curators sought to obtain a 
'type-set' of implements, or to off-load surfeit collections. ${ }^{6}$ Ernest Westlake was probably the first British man to go to Tasmania with the purpose of collecting stone artefacts in 1908, and formed what is possibly the largest single collection of its kind: over 13,000 stone artefacts, housed in Oxford University's Pitt Rivers Museum since 1923 (Taylor, Jones and McCarthy 2013). It is both profound as well as accurate to reflect that this vast accumulation of rock was inspired by just one stone.

The eagerness to accept large numbers of stone was not always so wholehearted. When The Reverend C. G. Wilkinson, principal of Launceston Grammar School, sent over sixty artefacts to the British Museum in 1901 they were acknowledged with gratitude, but Keeper Charles Read thought it 'rather illjudged' to claim the Tasmanian Aboriginal people were 'associated with paleolithic man any more than with any other race or similar culture period'. ${ }^{7}$ Read offered no explanation for his contrary opinion, adding only: 'this is a large question to which I shall not enter at present'. But it is possible that from the array and variation of Tasmanian stone work Read had been able to study in the British Museum, he could find no clear reason to consider the Tasmanians as especially simple. Nonetheless, due largely to Tylor, the idea of Tasmanians as the most primitive culture on earth was one of remarkable longevity. There was, however, at least one collector who shared Read's doubt.

\section{'JUSTICE DONE TO MY BLACK BROTHERS'}

In 1898, Joseph Paxton Moir the manager of the Taroona shot tower south of Hobart, wrote to the chief Hobart scholars of Tasmanian Aboriginal culture:, Alexander Morton, government statistician and geologist, R. M. Johnston and historian James Backhouse Walker. Moir explained that being surrounded by former Aboriginal 'camping grounds' that in his 'spare time' he had been able to 'dig over' some sites. ${ }^{8}$ He had found stone tools that demonstrated that the Aborigines were 'skilful and ingenious tool makers'. They could 'control the break of the stone so as to make ... curves... straight breaks and edges, and ... angles ...according to the intended use of the tool. 9 'We live 4 miles from the train terminus', he told them hopefully, 'but you would enjoy the walk'. ${ }^{10}$ They did not come; they did not even respond to his letters. ${ }^{11}$ So it was that Moir decided to write to one of the most eminent anthropologists of the day.

Moir admitted to Tylor that the only work he had read on the subject of Tasmanian anthropology was Tylor's 1894 paper. He had in fact avoided reading other material in order to 'prevent' his thinking from being 'warped', and leaving him able to offer some original thinking on the subject. ${ }^{12}$ While never losing their 
respectful tone, Moir's neat and careful letters persistently drew Tylor to one main argument: that the Tasmanians' cultural status should not be regarded as too low. He agreed that the Tasmanians were Palaeolithic, but came late in the culture phase, and were in fact 'on the eve of the Neolithic Age'.13 Moir described an implement as having ' 24 chips to the inch', and carefully sketched it so that Tylor might notice this when he was to later receive the artefact. Moir observed that it took 'more skill...to break a stone into shape than to grind it'. ${ }^{14}$ Moir drew pictures of hands cupping axes to demonstrate a lack of handle was no disadvantage. ${ }^{15}$

His letters to Tylor, written over eight years, are long and well thought out. Some were formal essays. Moir not only described the stone tools and where and when he found them, but drew them, suggesting their various uses, how they might have been held and creating numerous typological categories. He also sent Tylor many specimens for his collections. Moir complained to Tylor, 'very few here take any interest in Paleolithic matters and the members of the Royal Society (Tas.) do not care to acknowledge my communications because I do not belong to their circle or clique'. ${ }^{16}$ Moir had read their thoughts accurately. Walker admitted privately to Roth that he found Moir's ideas 'fanciful'. ${ }^{17}$

But Tylor also wrote to Roth. In his opinion, Moir's discoveries should be included the second edition of The Aborigines of Tasmania. Tylor was particularly interested in a new type of tool Moir called a 'duck bill', named after its beak-like nodule. Moir imagined it would have been used for fine wood design. ${ }^{18}$ Roth responded to Tylor: 'I am...in the dark as to what the Tasmanian could have used a duck bill stone for' ${ }^{19}$ But Tylor insisted, and as he told Roth, Henry Balfour, curator of the Pitt Rivers Museum, agreed. Four illustrations of Moir's tools (including the 'duck bill') featured in the second edition (Roth 1899: 145). ${ }^{20}$ Roth later complained to Walker of the inclusion: 'I have (strictly entre vous) very grave doubts but both Tylor and Balfour are against me and so I give in to superior judgment'. ${ }^{21}$

In the Preface to the new edition, Tylor wrote, with reference to Moir, that the Tasmanian stone tools showed the 'delicacy...as seen in neolithic work' (Tylor, 1899: viii). The following year, he presented one of Moir's letters to the Royal Anthropological Institute, stating that '[f]or variety of form and purpose and ingenuity of chipping, the Tasmanians hold their own against Australian implements' (Tylor 1900: 258). 


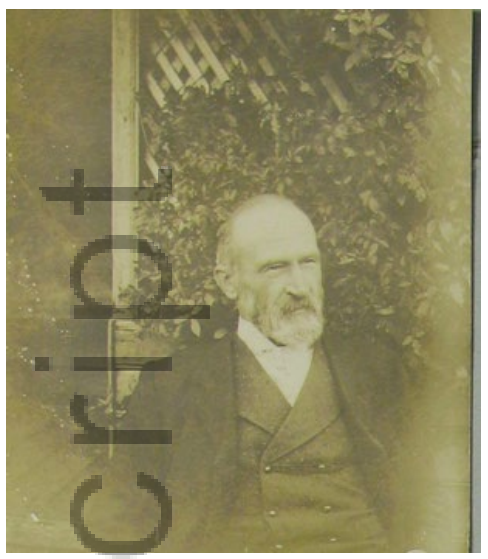

Figure 1 Joseph Paxton Moir sent this photograph of himself to EB Tylor in 1905 after seven years of correspondence. Pitt Rivers Museum: Photograph Collections, Westlake Collection: 1998.544.1. Accessed online via: Stories in Stone: an annotated history and guide to the collections and papers of Ernest Westlake (1855-1922), Image 14, WESTooo20, Series 2:

http://www.westlakehistory.info/viewer/WEST/item/WESTooo20/14

Joseph Paxton Moir sent this photograph of himself to EB Tylor in 1905 after seven years of correspondence: Pitt Rivers Museum: Manuseript Collections, Westlake Papers, Folder 4. Available online via: Stories in Stone: The Collections of Ernest Westlake (1855-1922), , Image 14, WESTOOO20: http://www.westlakehistory.info/viewer/WEST/item/WEST00020/14

After nearly seven years of correspondence Moir wrote with gratitude to Tylor that he had placed the Tasmanian Aboriginal people '... in a better light and exhibited their capabilities as clever and ingenious stone-breakers....':

This result alone is sufficient to repay and qualify me for my interest and work in this Tasmanian phase of the Stone Age (partly perhaps because I am a white Native of Tasmania and wish justice done to my black brothers). ${ }^{22}$

Moir sought reparation in evolutionary science. He made the designation of Late, rather than Early Palaeolithic an act of compassionate reparation. If the colonised society was not so 'low', Moir's logic seemingly followed, and then their destruction could not so easily be vindicated as natural. Tylor's first aim was not to vindicate colonisation, but by reducing Aboriginal society to the representatives of Europeans' 
distant past he facilitated that aim by extension of logic. But the logic has an inherent contradiction. In order to make the Aboriginal artefacts represent the culture of a distant time and place, Tylor had to abstract Aboriginal artefacts from their own historical and social context. In contrast, Moir understood the stone implements he collected within the spaces where they had been made and used; the old camping grounds, the middens and beaches, but more; he knew the stories and memories that went with those places. He knew the reasons that he was able to pick up that which was once an implement of simple use; that had been the property of someone else.

Moir sent a photograph taken in James Watt Beattie's Hobart studio of what is presumably his own hand holding a stone tool. His stiff shirt and jacket cuffs seem incongruous with the stone tool and with the person who once used it. While Moir's hand replaces the original owner's hand, it also remembers it, and its efficacy. Moir hoped to demonstrate that a handle was not essential to a useful axe. But the photograph is not only proving a point of anthropological detail; it reflects the justice Moir hoped his science could do for his 'black brothers'.

But while Tylor acknowledged the Tasmanians' 'finer' work in his Preface to Roth's second edition, he also concluded that their culture status should nonetheless be 'judged' by their 'general' character of which Taunton Scraper remained indicative (Murray 1992: 735). But his original impression, formed on seeing that first stone implement, now had a comparative evolutionary phase even more ancient than the first cave dwellers. It was the 'oldest and rudest palaeolithic implements found in Europe: the plateau-flints of Kent' (Tylor 1899: viii). It is interesting that Tylor chose to refer to the 'plateau-flints of Kent' as 'paleolithic' when their discoverer, Benjamin Harrison, the storekeeper of the Ightham village, considered them to have dated from the earlier, controversial culture phase called the 'Eolithic'.

The discovery of a Pleistocene human antiquity in 1859 had 'opened the gates' for an even deeper antiquity: scientists 'expected' to find artefacts in increasingly earlier deposits of gradually cruder style as they traced humans back to the hominids of Darwin's theory of biological transmutation (Grayson 1986: 79). While geologists could determine the age of excavated material by stratification, the emergent discipline of archaeology struggled to discern human-made stone tools from rocks broken by natural causes. From this inability there emerged a heated, but formative debate over the age of human antiquity as European scientists claimed to find stone tools that dated from before the Pleistocene, from the 'Tertiary' geological period, hundreds of thousands of years into the past. By the mid-twentieth century these 'tools' were realised to be what the sceptics had always claimed from the outset: naturally broken stones. 
Harrison's 1885 finds were the first claims to Eolithic stone implements in Britain, and they roused considerable debate. But it was significant that the archaeologists Prestwich and Lieutenant-General Pitt Rivers considered them genuine (Roe 1981: 217). Pitt Rivers wrote to Tylor on the subject of Eoliths in 1898:

Has it occurred to you that your Tasmanian flints, the flat ones chipped only at the edge that you shewed me at Oxford, are exactly like Mr. Harrisons [sic] chalk plateau flints that he considers prePalaeolithic [sic] and calls Eolithic? ${ }^{23}$

A year later, Tylor echoed this comparison in the Preface to the second edition of The Aborigines of Tasmania. In 1905, Tylor wrote to Moir that he was working on his final book, Growth and Spread of Culture. It was to be his last effort to illustrate his monumental ideas of evolutionary human development. ${ }^{24}$ But this last treatise was never published. The manuscript in the Pitt Rivers Museum archives reveals rough notes of the first chapter entitled 'The Eolithic Age and [the] Tasmanians'. ${ }^{25}$

It was during these final years of his work that Tylor had several plaster castes of the Taunton Scraper made, 'to give to certain museums'. At his request, the assistant Secretary and Curator of Taunton Castle Museum, H. St George Gray, sent one to Charles Read, keeper of the British Museum, describing it as 'the famous Tasmanian stone implement' from their collection. Gray added that 'Dr. Tylor never comes here (and he is often here) without asking to see our Tasmanian implement'. ${ }^{26}$ If the Eolithic Age was contentious, it was also appealing. Even its name reflected how Tylor had always seen the Taunton Scraper: the symbol of the dawn of humanity.

The Taunton Scraper had been at the centre of Tylor's thinking for forty-five years influencing the central role he played in the disciplinary transformation of ethnology into evolutionary anthropology. This shift is illustrated clearly by the distinction between Tylor's 1865 reference to the Tasmanians as the 'lowest tribes known to ethnology' with his 1894 'Representatives of Paleolithic Man'. More significant than the abandonment of the word 'ethnology' is that the Tasmanians are no longer 'known', but had become 'representatives' standing for another time, place and people, and not for themselves. As geologist W. J. Sollas wrote in his 1911 book, Prehistoric Times: 'the real value of what little we know about the Tasmanians lies in the analysis it provides ... of the earliest relics of Palaeolithic man' (Sollas 1911: 70).

If ethnology had aimed to tell a global story of human diversity or unity across space, then anthropology became a science by 'shedding' this historical vision; it 'defined itself against history', in order to interpret culture according to 'general laws 
across time' (Griffiths 1996: 25-26). Societies were organised along an 'axis of assumed structural ideational archaism', with Victorian European society occupying the most advanced end of the spectrum, the Tasmanians at the other (Keen 2000: 89). It was, Sollas admitted, 'a wilfull [sic] anachronism', willful presumably for the thousands of years and kilometres that separated the two societies (Sollas 1911: 70).

It seems contradictory that a theoretical framework that collapsed time and space should have emerged out of the disciplines that measured the past. Geology had offered up the vast expanse of time required for the transmutation of species; paleontology demonstrated that theory by revealing extinct life forms; and archaeology, born out of the discovery of human antiquity, was the first discipline to map culture in the 'ages' of Stone, Bronze and Iron and compare them with living societies (Keen 2000: 79). As anthropology adopted this framework, evolution became determined rather than random, as it was within Darwin's biological definition. Nonetheless, Darwin succumbed to this progressive view of culture (Griffiths 1996: 10).

Tylor not only called primitives 'representatives' of earlier culture phases, but also the 'survivals'. In the case of the Tasmanians, the term offers up a strange irony. To be 'survivals' and extinct required the Tasmanians be at once outside history and also the subjects of its tragic reality. But within the framework of nineteenth-century evolutionary anthropological theory, time and history were not the same. If the Tasmanians had occupied their 'remote corner' since the 'early ages', as Tylor put it, they had 'gone on little changed'; they had been locked in a Palaeolithic, or even Eolithic stasis. The only history that Tylor acknowledged the Tasmanians possessed had ended in 'total extinction'. Indeed, being 'confidently declared extinct', was for the Tasmanians, 'the only alternative to being timeless' (Griffiths 1996: 25-27).

\section{THE LAST TASMANIAN}

During the 1890 s the Aboriginal population of Tasmania was active, vibrant and growing. There were over a hundred indigenous peoples centred on Cape Barren Island in the Bass Strait. Their community had emerged out of the colonial maritime frontier opened by the sealing trade that operated from the late 1790s. European 'Eastern Straitsmen' made the islands their homes from the 1820 s. Their wives, the tyereelore, were chiefly from the Coastal Plains and Oyster Bay Nations of the northeastern coast of Tasmania. Their children grew up knowing their fathers' and mothers' languages and traditions. It was what descendant of four tyereelore and 
their Straitsmen husbands, Patsy Cameron, describes as a 'blending of two cultures' from which sprung a 'new lifeworld and a new peoples of the islands' (Cameron 2011: ix, 97-122, 154).

At the southern end of Tasmania_lived Mrs Fanny Smith who was born on Flinders Island in 1834 or 1835 to Aboriginal parents. She was a cultural and spiritual leader of her community at Irish Town, later Nicholls Rivulet. By the 1890 os her eleven children had families of their own. They continued to remember Mrs Smith's language and traditional practices. There were also other Aboriginal families at this time living in various parts of Tasmania. (Ryan 2012: 275)

These communities were not, however, considered Aboriginal by their contemporary white society. Extinction was a concept based upon an understanding of blood as both a conveyor of racial distinction and as being quantifiable: it could be mixed and measured in parts to create 'half' or 'quarter-castes', but these hybrids could not, in this logic, represent the original, 'pure' race. As Russell McGregor explains, the extinction of the Tasmanians 'referred not to the demise of all persons of ... Aboriginal descent, but to the disappearance of a supposed racial entity' (McGregor 1997: 51, 53).

But it was in keeping with this logic that in 1889, Tasmania's government printer, James Barnard wrote to the journal, Nature, that Mrs Smith, then aged 55-years, was 'upon her own testimony' a 'full blood' Aboriginal and 'the 'last survivor' of her 'race'. Mrs Smith's parents who were both 'undeniably aboriginals', asserted Barnard, a fact which had been endorsed by Tasmania's Parliament. (Barnard 1889: 43). Henry Ling Roth read Barnard's letter with fascination and incredulity.

Roth was a businessman whose work had taken him to Eastern Russia, British Guiana, and, from 1878, a ten-year residency in north Queensland consulting for the sugar cane industry. This inspired and paralleled a range of scholarly interests from entomology to anthropology. The Aborigines of Tasmania, was his first book and Roth sought to 'establish complete authority' over the subject. (McDougall 2007: 47). Tylor praised Roth's, 'long and conscientious labour' to compile 'to absolute completeness ... the notices scattered through voyages, histories, colonial documents and ... first-hand information, however fragmentary' (Tylor 1890: viii).

It was a desire to check the veracity of Barnard's claim in his book that initiated his first letter to James Backhouse Walker in Hobart. By then Roth's book was in press, and it was too late to include any new findings. But Roth's interest in Mrs Smith instigated eight years of work on a second edition, which was directed and informed by Walker's extensive assistance from 1891 to 1899 . 
Walker's first scholarly interest was the history of Tasmania's discovery and settlement. He was also a busy barrister, an active member of the Royal Society of Tasmania, a member of Tasmania's Board of Education, its university's second vicechancellor, and a Trustee of the Public Library. A friend and advisor to pastoralists, politicians and premiers, Walker's house was an intellectual and literary centre of Hobart (Felton 2102: 1, Smith 1976).

Roth wrote to Nature that Barnard's claim lacked a description of Fanny's 'features' detailed enough to determine her as a 'pure-bred aborigine' (Roth 1889: 105).To this end Roth asked Walker for help acquiring a 'fairly large portrait' photograph of Mrs Smith ('full face and profile'); for hair to be taken from her head, her armpits ('if it grow there') and 'from the pubes'; and, a 'concise scientific description of her physical characteristics'. The request went further: 'On her death her skeleton should be preserved and sent home to be examined by an expert ... it could be consigned ... to the agent general in London so as to ensure its safe return to Tasmania'. ${ }^{27}$

The astonishingly insensitive request was in keeping with the blatant descriptions and images of stolen Tasmanian Aboriginal ancestral remains reproduced in Roth's book. His presumption this theft was appropriate academic practice resounds in his use of the word 'home'. It is not that he considers England to be Mrs Smith's home (he suggests plans for her body to have a 'safe return'), but the home of 'expert' study, and, no less presumptively, the 'home' of Hobart-born Walker. The word bespeaks the condescension of a generation and of an Empire.

Walker's response was politely understated. He advised that the procurement of Mrs Smith's skeleton, was 'a rather a delicate matter' that would pose 'some difficulty'. (He was perhaps remembering the public uproar that followed the dissection of Lanne's body in 1869.) Walker was probably correct when he surmised that Mrs Smith's 'husband might very likely object to allow the dissection of her body in case of her death'. Walker did, however, think he could attempt Roth's others requests. ${ }^{28}$ But more than a year passed before Walker reported to Roth that Mrs Smith 'is yet an unattained object...' The phrase reaffirms the dehumanising effect of Roth and Walker's correspondence and of the ideas of physical anthropology that could reduce a living person to the value of her body and its parts. After another six months Walker had delegated the task of obtaining a photograph of Mrs Smith and continued to supervise the issues from afar. ${ }^{29}$ Indeed, he did not actually meet Mrs Smith until after Roth's second edition had been published in 1899.

The fact Walker was in 'no doubt' that Mrs Smith, was a 'half caste', perhaps made him less inclined to urgency. But it was also because Walker's time was divided, and 
at times his health was compromised. Walker sometimes found it hard to carry out research for Roth and his responses were often protracted. But these difficulties made his efforts all the more significant. Walker's 'unsurpassed knowledge', and 'never failing keenness', Roth acknowledged, were of 'inestimable value'.30 At Roth's insistence, Walker was listed as assistant author in the frontispiece of the new edition (Felton 2013: 24, Mcdougall, 2007: 51).31

One of the first tasks that Walker was inspired to complete for Roth was to write a brief history of settlement, a subject he thought had suffered 'much misrepresentation' along with a comprehensive guide for reading 'the principal writers of the Aborigines'. ${ }^{2}$ Walker had more a comprehensive knowledge of the Aboriginal records than Roth, and a local's grasp of events and politics. He sought to caution Roth of the unreliability of the historical sources regarding the Aborigines. The journals of the French explorers who made first contact were 'saturated' with 'fashionable fancies of the Rousseau school'; the oldest remaining settlers remembered Aborigines only as 'treacherous foes' owing to the 'deadly feud' that began around 1824; G. A. Robinson, Government Conciliator "who brought in the blacks' was the only writer who had known the Aborigines 'in their wild state', but his voluminous reports included too many 'personal adventures'; and, finally, the efforts to record their customs when they were incarcerated on Flinders Island came thirty years after settlement, by which time the Aborigines had 'picked up' many new 'ideas and practices'. 33

Walker's parameters were rigorous. The idea of extinction challenged certainty; the supposed absence of living Aboriginal people meant there was no measure against which to test the authority of any fact gleaned. But the challenge held appeal. It turned historical research into relic hunting; the search for the last vestiges of something pure but lost. Indeed, the idea of extinction was a large part of what drove Roth and Walker's long and shared interest in the Tasmanians.

While the written sources were inherently unreliable, the physical remains of the last 'wild' Aborigines had, according to Walker's standards, retained their authenticity. At his instigation, Walter Harper and Arthur Clarke examined nineteen Aboriginal skulls housed in the Tasmanian Museum in Hobart. 34 Roth sent instructions on how to determine craniometrical capacity: they poured lead shot into the upturned skulls and then transferred into a glass gauge, also sent by Roth. 35 Three skulls were rejected from the study as belonging to 'half-castes', and three because they were not known definitively to have belonged to Tasmanians (Harper and Clarke 1897)..$^{6}$ It was the collections' largely vague provenance that led Walker to spend over a year trying to access a collection of six Tasmanian Aboriginal skulls in 
the possession of Edward Cotton whose family had lived at Kelvedon on Tasmania's East Coast since 1829.37 The skulls in Cotton's possession were 'most desirable', Walker told Roth, as he knew 'the history of each, and they are undoubtedly Tasmanians'. But, he complained, no 'competent person' had time to travel up to the East Coast to measure them. ${ }^{38}$ Walker's own efforts were hampered by illness and time constraints. ${ }^{39}$ Bishop Montgomery finally extracted a promise from Cotton to send the skulls down to Hobart. '[I]f only these could be measured in time for publication', Roth worried, but Cotton did not keep his word. ${ }^{40}$

When Walker learned that Roth's few samples of Aboriginal hair had been lost by the Pitt Rivers Museum, ${ }^{41}$ he tried to extract from a matted, and 'much ochred', lock of hair that he had, a few strands long enough to be of 'use'. ${ }^{42}$ The hair had belonged 'either' to Wooreddy or Mannalarganna, Aboriginal leaders who had negotiated with the colonial government on behalf of their people. Roth received the hairs with sanguinity: 'it is really sad to dwell on their fate'.43 But he was 'extremely obliged', to later receive a piece of Truganini's hair that Walker had secured from Clarke. He thought it a 'most interesting relic' and promised it would be 'carefully preserved'.44

The vestiges of the supposed extinct Tasmanian Aboriginal people were given far higher value by both Roth and Walker than any information remembered by, or concerning, their living descendants. Beattie offered to send Roth a 'very successful' photograph of five Cape Barren Islanders taken by Bishop Montgomery in 1893: 'all the pure halfcastes now alive'. 45 The curiously contradictory term referred to the adult children of the first tyereelore and Straitsmen island settlers, but Roth was not interested in acquiring the image. He, with Walker's guidance, ignored the Islander community and overlooked the significance of their enduring cultural knowledge. When Roth asked Walker to obtain an Aboriginal shell necklace, Walker explained they were 'commonly for sale here' but since the 'half-caste' islanders made them, they were not 'genuine'. He thought there were only about three 'native' necklaces left in the colony. ${ }^{46}$ Roth passed on his wife's thanks nonetheless; she planned to display the necklace in their drawing-room. ${ }^{47}$ When Roth later asked if it was true, as he had been emphatically told in England, that there were some 'aborigines' living in the Bass Strait, Walker responded unequivocally: 'The islanders ... are not aborigines, but half-castes - a mixed breed of Tasmanian, Australian, and European, with a dash of Maori'. 48

While the Islanders were discounted as reliable informants, Walker considered written and oral sources from certain white colonists to be trustworthy. He took notes from second-generation settlers Cotton and G. H. Rayner on how Aboriginal people made fire (Roth 1899: 1xxxxviii, 83-84; Taylor 2008: 7-9; Walker 1900: 5).49 Walker 
found a hitherto undiscovered vocabulary of Aboriginal language in the journals of his father, George Washington Walker, recorded on his travels with fellow Quaker Missionary, James Backhouse in 1832 to Tasmania's Aboriginal settlements. $5^{\circ}$ With Tasmanian government statistician and geologist R. M. Johnston and W. N. Hurst of the Lands Office, Walker had offered Roth a new map of Aboriginal tribal boundaries and place names (McDougall 2007: 53). ${ }^{11} \mathrm{He}$ took a journey with Beattie and Johnston to an Aboriginal quarry that Rayner insisted was 'unknown'. ${ }^{52}$ This was the only journey Walker carried out for Roth. He had tried hard to travel to Cotton's at Kelvedon, but he had never showed much interested in going to see Mrs Smith, having little doubt she was a 'half caste'. Instead, Walker had passed on Roth's requests for Mrs Smith's physical details to his friend, J. W. Beattie. 53

Beattie had been 'intensely' interested in the Tasmanian Aboriginal people for many years. His large Hobart photographic studios displayed a 'very complete collection' of their photographs, among other historical artefacts. He promised Roth to secure photograph of Mrs Smith soon as she was often seen in Hobart. ${ }^{54}$ He was still waiting six months later.55 By the time a year had passed, Beattie sent his brother down to Port Cygnet, 'with full instructions' and orders 'to stay till he gets her to sit, if it takes a fortnight'. He went with several photos of 'her people' to use 'as a bait': should she agree to be photographed again in Hobart, she would be given more. ${ }^{6}$ Mrs Smith could not be enticed to Beattie's studio, but his brother successfully procured the images and hair in Port Cygnet. When Roth finally received them, he found he agreed with Walker: 'I do not think she is a pure aborigine'. But as he was still waiting on an expert report on her hair sample, Roth wrote that he 'would rather this opinion is not yet made public' (Roth 1899: 1xxxvi). ${ }^{57}$ In the interim, Roth sought descriptions of Mrs Smith's 'mental' and 'physical' details including her blood status. Beattie dutifully sent out letters to those who knew her well requesting this information. $5^{8}$

The two of Mrs Smith's friends who responded would not condescend to Roth's scientific terms. Former Wesleyan parson of Port Cygnet, A. J. Holden, stated that 'physically' Mrs Smith was a 'marvel'; 'mentally', she was 'very bright'.59 Mr A. Geeves of Hobart described his friend as a 'Christian woman who was 'well respected...by all who know her'. ${ }^{60}$ Both men agreed Mrs Smith was a 'full-blood' Aboriginal. 61 'She certainly believes herself to be', wrote Holden. But if her own testimony could convince Roth he would not have persisted with his inquiries in the first place. He instead asked Beattie to try and get a description of Mrs Smith's teeth. Beattie responded with incredulity that her friends, 'excuse themselves by telling me it is a rather a delicate matter!'62 
One of Mrs Smith's friends did tell Beattie how Mrs Smith spoke of her people as 'telepathists': they 'knew when any accident happened to any relative'. Her mother would also 'sit and look at the stars' and 'give them names'. They had 'religious belief': '...good and evil spirits, blessing or hindering'. ${ }^{63}$ But Roth reported none of this. Nor when he learned from both Walker and Beattie that Mrs Smith planned to go to England ‘to see Queen Victoria' he did not express much interest. ${ }^{64}$ (Mrs Smith never made this visit). In early 1898, Roth presented his conclusion on the matter to the Anthropological Institute: Mrs Smith's facial features were clearly that of a 'halfcaste'. ${ }^{6}$ It was, he reflected to Walker; 'a result I must confess a little disappointed at'. ${ }^{66}$ To discover the last Tasmanian Aborigine would have been an academic coup.

These disturbing efforts reveal Roth and Walker's research as a kind of morbid relic hunting. Walker understood that Roth's goal was not only encyclopedic completeness, but the acquisition of the most valuable facts and artefacts that remained from the presumably dead Tasmanian Aboriginal people. Here the concept of extinction extended beyond blood quantification, indeed it extended beyond Aboriginal bodies. It created in its relief the idea of something pure but lost; something destroyed not only by death and miscegenation, but the imperfection of historical accounts and tainted or vanished memories. It made the anthropology of Tasmanian Aboriginal people not just one of salvage, but also of careful interpretation, sifting and even rejection: not just the 'half-caste' skulls but also their contemporary necklaces, even the, 'half-castes' themselves. These were perceived not as evidence of a continuing and living Aboriginal culture, but the evidence of inauthenticity and absence. Such interpretation required expertise. The idea of extinction created hierarchies and cliques of knowledge. Walker sat at the centre of that 'clique' as Moir had termed it, and his influence was considerable.

Hobart, not England, was Walker's true 'home'; his own social and intellectual hub from which he, nor Beattie, rarely left. Engaged in their businesses, they, like Roth, carried out most of their research by correspondence. He was prepared to travel only where he deemed the information would be worthwhile. Moreover, Walker was aware of the rich collection of manuscripts, memories and collections that were already to hand in Hobart museum and private collections. Nonetheless, Walker often wished he could travel further afield. He even urged Roth to visit.

'Why not take a six month holiday, and come and study the Tasmanian question on the spot?', Walker asked Roth in 1897: 'You would learn more in a month here, than in years of correspondence. ${ }^{67}$ By this time Roth had been working on his second edition of The Tasmanian Aborigines-The Aborigines of Tasmania for six years, and would do so for another two, incorporating the research that Walker carried out on 
his behalf. Despite the sagacity of Walker's advice, Roth did not go to Tasmania. Roth could not leave his business, his next book, his new wife and their baby son. ${ }^{68}$ But nor did Roth need to: he had in Walker a meticulous expert. Walker never assumed himself to be a professional. While he directed and influenced Roth's work, he understood his role was to underpin Roth's ideas, and in particular his goal to determine the Tasmanians' extinction.

Walker and Roth believed in their thoroughness, tenacity and high scholarly standard. When Walker finally received the second edition of The Tasmanian Aborigines The Aborigines of Tasmania he was 'exceedingly pleased'. He congratulated Roth for having 'the final word on our unfortunate Aborigines' and leaving 'very little indeed for any aftercomer to glean.' 69

It was not until after Roth's second edition was published that Walker met with Mrs Smith. With Bishop H. H. Montgomery they recorded her Aboriginal songs onto a gramophone. 'It seemed to me to be soft and pleasing...', Walker reflected, but he did not expect to gain any more 'that is valuable' from her. He considered the greatest benefit of meeting her was confirming the illegitimacy of her own testimony:

If you could have seen her, you might have made your paper much stronger. She has a pink tinge in her cheeks, and is manifestly a half caste. The Bishop said so at once...70

But Roth never saw Mrs Smith's 'pink' cheeks. He determined her blood status in Halifax from samples of her hair, physical descriptions made by others, but foremost from the photograph sent by Beattie. Photography already had an established place in the scientific definition of Tasmanian Aboriginality. The portraits of residents of Oyster Cove photographed from the 185 os had been reproduced widely in books, postcards and albums from the 1870 . They marked what Tasmanian Aboriginal historian and artist, Julie Gough observes was an 'abrupt and dehumanising shift' in the photography of Tasmanian Aboriginal people from 'art' to photography as 'a tool of science'. As such they played a key part in the 'official determination not to recognise' Aborigines living in the other parts of Tasmania (Gough 2014 pp 36-37).

Roth was familiar with the Oyster Cove images; many featured in his book. But he 'saved' perhaps the best-known photograph, Charles Woolley's portraits of Truganini, for the penultimate pages of the book in order that they could appear along side those of Mrs Smith and thus 'force the comparison'. It was an effective ploy (McDougall 2007: 57). Reviewer Andrew Lang agreed that Roth's evidence was 'conclusive, and 
instantaneous': Mrs Smith's face 'might pass for a true blue, jolly, British landlady', but Truganini's face was, 'black, hideous': the 'face of a pure Tasmanian savage ... the last of a people who... still lived... the life ...of the Palaeolithic age - the mammoth period of Europe' (McDougall 2007: 57-58). Lang converged Tylor's concept of the Tasmanians as the representatives of the Paleolithic with Roth's determination of extinction. He then compared the Tasmanian Aboriginal people to the British colonists whom he described as evidently being a race of 'superior endurance, and intelligence'.

Lang did more than converge Tylor's idea of the 'Palaolithic' Tasmanians with Roth's assertion of extinction, he questioned Tylor's comparative evolutionary framework. How could the Tasmanians 'represent' the early Europeans when they were extinct? For the Europeans had been a 'white race, with all its superior endurance, and intelligence, or capacity of becoming intelligent' (in McDougall 2007: 49). In order to celebrate British racial superiority Lang not only has to challenge the universality of Tylor's definition of culture, he has to manipulate his notion of the representative 'Palaeolithic' away from the comparison between the stone tools, to become part of Roth's interest in racial typology determined by studies of hair samples and photographs. But Tylor had not sought the physical representation of the Palaeolithic, only its material cultural counterpart. For him the Tasmanian Palaeolithic did not die with Truganini, but lived conceptually, in the continuing presence of their stone artefacts.

This distinction between Roth's and Tylor's research goals is realised in their correspondence. To determine that Mrs Smith was not the 'last' Tasmanian required years of indefatigable letter writing. Tylor's goal hardly required any correspondence at all. His designation for the Tasmanians was confirmed through the repeated visits to the Taunton Museum. While Moir, 'surrounded by camping sites' unearthed unusually well-made tools, Tylor could acknowledge these variances with interest even to the chagrin of Roth - without it disturbing his larger thesis.

The difference between the researchers' objectives is further realised in their approaches to Tasmania's past. Roth was intensely interested in that history, both as a mine for anthropological information, and in its outcome, extinction. Tylor was not drawn to explore the end of Tasmanian Aboriginal history. Rather, in one abstracted artefact, he sought to discover the beginnings of human history. This encapsulation not only made the Tasmanian Aborigine_people recent past largely irrelevant, it denied them any real history at all. 


\section{EPILOGUE: 'A REAL, DEEP PAST’71}

'Traditions die hard', wrote Australian archaeologist John Mulvaney in 1961. He reflected while Tylor's conclusion, drawn from the single Taunton Scraper, had lead to a persistent and widespread belief that the Tasmanian Aboriginal peoples' stonework was inferior to that of Australia's mainland Aborigines. But, Mulvaney asserted, the Tasmanians' stone tools included 'specialised type and fine craftsmanship'. His reference was to the 1925 paper by Henry Balfour, Keeper of the Pitt Rivers Museum which was based on the study of the vast collection of Tasmanian Aboriginal artefacts formed by Ernest Westlake from 1908-1910 (Mulvaney 1990:

45).

Balfour concluded that the Tasmanians' cultural status had been 'marked too low'. He thought that to do 'justice to the native potentialities', it was important to draw conclusions not from their 'general' work (as Tylor had done), but from their 'highest attainments'. Balfour 'put forward a plea for a correlation' between Tasmanian stonework and Europe's middle Palaeolithic period; the 'post-Mousterian culturephase, to wit the Aurignacian' (Balfour 1925: 3-14). Balfour thus declared 'the socalled "Eolithic Tasmanian" is a pure myth' (Balfour 1929: 315).

Mulvaney thought Balfour had been the 'the first' to demonstrate the full capabilities of Tasmanian stone making, and remained in 1961 the most detailed on the subject (Mulvaney 1990: 45). But Joseph Paxton Moir had pre-empted Balfour. It is possible that Balfour read not only the published accounts of Moir's correspondence to Tylor, but the letters themselves, which were accessible to him in the Pitt Rivers Museum (and may explain how Moir and Tylor's correspondence came to be stored with Westlake's papers). Certainly Balfour owed to Moir not only the conceptual basis of his thesis, but the identification of some of the tool types he refers to, including the 'duck-bill scraper' (Balfour 1929: 320). One of the clearest echoes of Moir's writing - if perhaps coincidental - is Balfour's use of the word 'justice', for it was 'justice' that Moir hoped his efforts might have offered his 'black brothers'.

Moir's ideas had been not only outside the mainstream of British scholarship, but that also that of his own town. Yet over time, they came to be accepted by leading scholars. An important parallel is found in Alfred Howitt's suggestion that the Tasmanian Aboriginal people had originated from a Pleistocene Australia. The idea found some interest locally. For over a decade, stone tool collector, Alfred S. Kenyon, scoured Victoria's coastline for stone implements that might draw a typological 
connection between Tasmania and Victoria. In 1899, Howitt wrote to Tylor of Kenyon's findings. But Kenyon then became one of Spencer's closest acolytes, and it was perhaps under his influence that Kenyon agreed that a typological connection did not mean evidence of antiquity, concluding finally that Aboriginal people had not been in south-east Australia more than a few thousand, or even few hundred, years. Most of Kenyon's fellow members of Victorian 'stone circle' shared his conservatism well into the twentieth century (Griffiths 1996: 72-79).

In 1923, T. W. Edgeworth David extended Howitt's ideas, suggesting that the simplicity of Tasmanian Aboriginal material culture and the absence of the dingo pointed to an older Pleistocene link with Australia. But his thesis was largely rejected, in favour of relatively recent migratory sea journeys from the Melanesian region, (although leading Australian archaeologist, Norman B. Tindale argued that the Tasmanians' migration did not necessarily negate a deep history) (Pulleine 1928; Tindale 1937-41; Wood Jones 1935: 11). The debate turned increasing attention to Tasmania's north-west corner to determine either a former link to the mainland, or an older migratory route. Stone tool collectors had found surface artefacts from the area since the late nineteenth century. From the early twentieth century amateur archaeologists followed with shovels, attempting to determine a chronological sequence (Jones 1971: 36-52; Pulleine 1928; Tindale 1937-41). John Mulvaney argued finally that the area required 'systematic excavation' (1961: 48).

This is what Cambridge graduate, Rhys Jones set out to achieve in December 1963 (Mulvaney 2001: 19). The first professional archaeologist to carry out fieldwork in Tasmania, Jones's carbon-dated sequencing effectively solved the Tasmanian 'problem' and confirmed Howitt's contention (Jones and Meehan 2000: 40). But it also raised a new question. His sequencing revealed that from 3500 years before present that there were no discarded scale-fish bones in the midden sites. This suggested to Jones evidence that the Tasmanian people had, without ostensible good reason, ceased catching scale-fish. They had seemingly become 'simplified' (Horton 1979: 170; Jones 1971: 603, 620; Jones 1978: 26-27). Jones extended the idea to a lost ability to make fire. He then pointed to a biogeographic cause: 'The world's longest isolation, the world's simplest technology'. Continuing the presumption that the Tasmanian Aboriginal people were extinct, Jones posed what became an infamous question: even if Tasmania had never been colonised, had the Aborigines been nonetheless 'doomed to a slow strangulation of the mind? (Jones 1977: 197, 202-203). The idea was repeated, to wide controversy, in Tom Haydon's popular 1978 film The Last Tasmanian. 
The film was launched just as the Tasmanian Aboriginal community began a struggle for recognition, rights to land and education that was characterised by the politics of radical self-determinism. They were outraged not only by the reiteration of their extinction, but Jones's supposed reasoning that it would have happened 'anyway' (Langford 1983: 5; Mansell 1978: 2; Ryan 1996: 254). They were joined by the academy, whose members accused Jones of ' $19^{\text {th }}$ century racist ideology' (Bickford 1979: 14); 'social Darwinism,' (Bowdler 1980: 335) and of being one of the many 'Apologists for an Extermination Policy' (Ryan 1985). Lyndall Ryan restated this critique in 2012 as 'scientific racism', after Rutledge M. Dennis's definition (1995), listing Jones, with Tylor, in a progression of scholars who have, since the 1850s concurred that the Tasmanian Aboriginal people had always been a 'doomed race' (Ryan 2012: $x i x-x x$ ).

It was this critical approach that helped ensure the wider recognition of Ryan's ground-breaking acknowledgement in 1981: 'the Tasmanian Aborigines have survived' (Ryan 1996: 257). Ryan restated this opinion in 2012 as part of her response to Keith Windschuttle's accusation that she had fabricated historical evidence. Ryan countered that a few tangled footnotes were never the real 'tinder' that generated the 'heat' of the 'history wars'. It was that her history of Tasmania was 'deeply influenced' by the successful Aboriginal campaign for the recognition of their survival (Ryan 2012: xxii-xxiv). Her point seems well illustrated when Windschuttle borrows Jones's allegorical 'slow strangulation' of the Tasmanian Aboriginal cultural 'mind' to argue that their society was also morally regressed, being 'so internally dysfunctional' that it was 'not surprising that when the British arrived, this small, precarious society quickly collapsed' (Windshuttle 2002: 386). But Jones's dissertation expounds without restraint upon the culpability of the British, going so far as to compare colonial Tasmania to the Holocaust (Jones 1971: 2, 8-9). Jones was inspired by a wider anti-colonial movement to explore a sense of national culpability in Tasmania's past, with Truganini as a figure-head for shame (Ryan 1997: 161-165). Haydon's film had the by line 'the story of the swiftest and most destructive genocide on record'.

But there is an echo between Jones's and Tylor's ideas (McNiven and Russell 2005: 64-66; Murray 1992: 738; White and O'Connell 1982: 170). For Tylor the Tasmanian Aboriginal people were the 'lowest' culture, for Jones they were 'simplest'. Indeed, Jones went further; he thought the Tasmanian Aboriginal people were unable even to make fire, an idea which Tylor had refuted outright (Tylor 1964: 249250). Moreover, Tylor had rejected the notion of regression and degeneration. For the ideas of 'low' and 'simple' are not synonymous. The first excludes a history; the 
latter depends upon it. Jones's supposed regression had not been fast, and its starting point was in the deep past. Indeed, its depth further explained simplicity: Jones, like Edgeworth David, saw in Tasmania an older vestige of a pre-Pleistocene Australia (Murray 1992: 738). As Jones himself put it, separating him from Tylor was a vast quantity of time and space:

We seem once more to be turning back to the classic problem of the Tasmanians as seen by Tylor. Can we now look to the Tasmanians, not so much as the representatives of Palaeolithic man, but of late Pleistocene Australian man? (Jones 1971: 630)

Jones was suggesting a shift of continents and the realisation of an Australian antiquity. He did not continue Tylor's metropolitan and anachronistic view of Tasmania, nor the justification of colonisation that such a view has been assumed to hold. Jones continued an antipodean view of Tasmania, in which archaeologists, since Howitt, had looked to the island as a key to the question of their own country's antiquity. Jones had effectively solved the 'problem of the Tasmanians'.

But solving that older 'problem' 'paled into insignificance', following the discovery in 1981 by Jones and others of a Pleistocene human occupation in southern Tasmania (Murray 1992: 739). The Kutikina excavations, Jones explains, revealed the distinctive culture of the 'southernmost humans on Earth', which had changed when the Pleistocene ended and forests enfolded grassy plains and higher seas flooded coasts. 'The Aborigines of Tasmania', Jones announced, 'long constructed as an abstract frozen metaphor for Palaeolithic man, are now seen as inheritors of a deep real past'. The shift away from Tylor's metropolitan view was total, and yet it recalled that older perspective in a new way: Tasmania now shared an antiquity equal with that of Palaeolithic Europe, making it possible, Jones explained, to realise a collective story of global migration and adaptation (Jones 1995: 423, 438-439, 441; Jones 1990: 290).

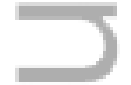

\section{CONCLUSION}

One of the most durable legacies of nineteenth-century British anthropology has been the prolonged power of the symbiotically fused ideas of the Tasmanian Aboriginal people as 'low' and 'extinct' to justify and celebrate British racial superiority. This has been sustained even when expressed within the context of 
shame. For the melancholia voiced over the Tasmanians' demise was at its inception demonstrably questionable in its morality, being as often a soliloquy to the loss to science, or the manifestation of a society so advanced it could question the cost of its progress to others less fortunate (Lawson 2014: 162-164, 109). Thus when extinction was substituted with the accusation of genocide in late twentieth century it could be mistranslated into colonial apology, and yet become rich ground for conservative criticism in the early twenty-first century.

While fused in their expediency, when returned to the level of personal correspondence, the two anthropological ideas of 'low' and 'extinct' emerge as separate research projects. The distinction is at first mundane: Tylor was not interested in acquiring crania nor in ascertaining the tightness of hair curls; Roth did not have a chief interest in whether Tasmanian stone tools were hafted, ground or chipped on both sides. But the distinction extends to the conceptual: in Tylor we find the search in Tasmania for the representative beginning to human cultural evolution; in Roth we find the search to determine their ending.

It is the colonial scholarly response to Tylor's ahistorical approach that clarifies most clearly the difference between Roth and Tylor's objectives - the antipodean aspiration to reveal in Tasmania a deep Aboriginal past offered an image in reverse of Tylor's objective to illuminate a European antiquity. As such it rejected the evolutionary comparative schema and helped to found an important new direction in Australian archaeology.

It is in realising the tensions, rather than the collusions, between colonial and metropolitan research interests and expertise, that it becomes possible to achieve a finer-grained reading of the scientific interest in the Tasmanian Aboriginal people one that moves beyond a presumed shared goal to justify colonisation into a more complex range of attempts to understand human history. It is out of this disambiguated space that it becomes possible to discern the originally intended goals of science, and to gain a deeper, more meaningful understanding of the ways those ideas have been used to shape British and Australian history writing and identities.

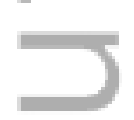

\section{REFERENCES}

\section{Archival sources:}

Correspondence between Joseph Paxton Moir and E. B. Tylor, 1898-1905, Westlake Papers (WC), Manuscript Collections (MC), Pitt Rivers Museum, (PRM). All the references to the WP, MC, PRM can be accessed digitally at: TAYLOR, R., with M. Jones, and G. McCarthy. Stories in Stone: an annotated history and guide to the collections and papers of Ernest Westlake (1855-1922). The University of Melbourne 
eScholarship Research Centre and the Pitt Rivers Museum, Oxford with the Oxford University Museum of Natural History. http://www.westlakehistory.info.

E. B Tylor Correspondence S-Y and Miscellaneous, Tylor Papers (TP), Manuscript Collections (MC), Pitt Rivers Museum, (PRM).

Correspondence to Charles Read, and Outletters, Department of Prehistory and Europe (DPE), British Museum, (BM), 1901-1905.

Correspondence to James Backhouse Walker from Henry Ling Roth, 1891-1899, W9_C19_1 to W9_C19_38, University of Tasmania Library Special and Rare Materials Collection, Australia (UTAS). http://eprints.utas.edu.au/17250/. Accessed 10 July 2015.

Correspondence to James Backhouse Walker from Joseph Paxton Moir, 1898, w9_c4_1(28)(1) and w9_c4_1(47)(1). University of Tasmania Library Special and Rare Materials Collection, Australia (UTAS). http://eprints.UTAS.edu.au/3276/. Accessed 7 July 2015.

Henry Ling Roth, Aborigines of Tasmania, 1919. List of Papers, Printed Pamphlets, Original MSS, Letters, Photographs, Drawings, Watercolours, Books, Prints, Stone Implements, Casts of Stone Implements, etc. relating to the above. I-XLI, Manchester Museum (MM). Referenced from this archive: XIII Jas. B Walker, XVI Various MSS; XIX 12 Letters from J. W. Beattie 1893-1897 (XIX JWB, MM); XX 32 Letters From James Backhouse Walker 1891-1899 (XX JBW, MM).

\section{Secondary published sources:}

BALFOUR, H. 1925. The Status of the Tasmanians Among the Stone-Age Peoples. Proceedings of the Prehistoric Society of East Anglia 5, 1: 1-15.

BALFOUR, H.1929. Stone Implements of the Tasmanians and the Culture-Status Which They Suggest. Hobart, Australasian Association for the Advancement of Science: 314-322.

BARNARD DAVIS, J. 1874. On the Ostelogy and Peculiarities of the Tasmanians. Haarlem: De Erven Loosjes.

BARNARD, J. 1889. Notes on the last living Aboriginal of Tasmania. Papers \& Proceedings of the Royal Society of Tasmania: 60-64.

BICKFORD, A. 1979. Superb Documentary or Racist Fantasy? Filmnews January: 14. BOWDLER, S. 1980. Fish and Culture, a Tasmanian Polemic. Mankind 12, no. 4: 334-340.

BONWICK, J.1870. The Last of the Tasmanians Or the Black War of Van Diemen's Land. London, Sampson Low, Son \& Marston.

BONWICK, J. 1884. The Lost Tasmanian Race. London, Sampson Low, Marston, Searle and Rivington.

CAMERON, P. Grease and Ochre the Blending of Two Cultures at the Colonial Sea Frontier. Launceston, Fullers Bookshop, 2011. 
CROZET, J. M. 1891. Crozet's Voyage To Tasmania, New Zealand and the Ladrone Islands and the Philippines in the Years 1771-1772, translated by H. Roth. London: Truslove and Shirley.

DANIEL, G. E. 1952. A Hundred Years of Archaeology. London: Gerald Duckworth.

DARWIN, C. 1871. The Descent of Man Selection And Selection in Relation to Sex. London, Murray.

DENNIS. R. M. 1995. Social Darwinism, Scientific Racism, and the Metaphysics of Race. The Journal of Negro Education, 64, 3: 243-252.

EDGEWORTH DAVID, T. W. 1923. Geological Evidence of the Antiquity of Man in the Commonwealth, With Special Reference to the Tasmanian Aborigines', Papers and Proceedings of the Royal Society of Tasmania: 109-50.

FELTON, H. 2012. Writing Tasmanian History: The Case of James Backhouse Walker. Tasmanian Historical Studies, 17: 1-44.

FFORDE, C. and HUBERT, J. 2006. Indigenous Human remains and changing museum ideology. A Future of Archaeology, eds. Robert Layton, Stephen Shennan and Peter Stone, London, UCL Press: 83-96.

FLOWER, W. H. 1877-1879. The Aborigines of Tasmania an Extinct Race. Science Lectures Delivered in Manchester. Manchester, John Heywood, Series 9 and 10.

GOUGH. J. 2014. Forgotten lives - the first photographs of Tasmanian Aboriginal people. Calling the Shots: Aboriginal Photographies, ed. Jane Lydon, Canberra: Aboriginal Studies Press: 21-54.

GRAYSON, D. K. 1986. Eoliths, Archaeological Ambiguity, and the Generation of 'Middle-Range' Research. American Archaeology Past and Future, eds. David J. Meltzer, Don. D. Fowler and Jeremy A. Sabloff, Washington: published for the Society of American Archaeology by the Smithsonian Institution Press: 77-133.

GRIFFITHS, T. 1996. Hunters and Collectors: The Antiquarian Imagination in Australia. Cambridge, England ad New York: Cambridge University Press.

HARPER, W. R. and CLARKE, A. H. 1897. Notes on the measurements of the Tasmanian crania in the Tasmanian Museum, Hobart. Papers \& Proceedings of the Royal Society of Tasmania: 97-107.

HORTON, D. 1979. Tasmanian Adaptation. Mankind 12, 1: 28-34.

HOWITT, A. 1898. On the Origin of the Aborigines of Tasmania and Australia. Australasian Association for the Advancement of Science 7: 723-758.

HUXLEY, T. H. 1870. On the Geographical Distribution of the Chief Modifications of Mankind', The Journal of the Ethnographical Society of London 2, 4: 404-412.

JONES, R. 1971. Rocky Cape and the Problem of the Tasmanian Aborigines. PhD Thesis, University of Sydney.

JONES, R. 1977. 'The Tasmanian Paradox' in Stone Tools as Cultural Markers, ed. R. V. S. Wright. Canberra: Australian Institute of Aboriginal Studies: 189-204. 
JONES, R. 1978. Why Did the Tasmanians Stop Eating Fish? Explorations in Ethnoarchaeology, ed. R. A. Gould. Albuquerque: University of New Mexico Press: 11-47.

JONES, R. 1990. From Kakadu to Kutikina: the southern continent at 18 ooo years ago. The World at 18 ooo BP, Volume Two, Low Latitutes, eds. Clive Gamble and Olga Soffer. London: Unwin Hyman: 264-295.

JONES, R. 1995. Tasmanian Archaeology: Establishing the Sequences. Annual Review of Anthropology 24: 423-446.

JONES, R. and MEEHAN, B. 2000. A Crucible of Australian prehistory: The 1965 ANZAAS Conference. Australian Archaeologist: Collected Papers in Honour of Jim Allen, eds. Atholl Anderson and Tim Murray, Canberra: Coombs Academic Publishing: 40-61.

KEEN I. 200o. The Anthropologist as Geologist: Howitt in Colonial Gippsland. The Australian Journal of Anthropology, 11, 1: 78-97.

LANGFORD, R. F. 1983. Our Heritage - Your Playground. Australian Archaeology 16: 1-6.

LAWSON, T. 2014. The Last Man: A British Genocide in Tasmania, London, I. B. Taurus.

LUBBOCK, J. 1865. Pre-historic Times, as Illustrated by Ancient Remains, and the Manners and Customs of Modern Savages. London: Williams and Norgate.

MACDONALD, H. 2005. Human Remains: Episodes in Human Dissection. Melbourne: Melbourne University Press.

MCDOUGALL, R. 2007. Henry Ling Roth in Tasmania. Writing, Travel and Empire: In the Margins of Anthropology eds. Peter Hulme and Russell McDougall. London and New York: IB Taurus: 42-68.

MCGREGOR. R. 1997. Imagined Destinies: Aboriginal Australians and the Doomed Race Theory, 1880-1939, Melbourne, Melbourne University Press

MCNIVEN, I. and Russell, L. 2005. Appropriated Pasts: Indigenous Peoples and the Colonial Culture of Archaeology. Oxford: AltaMira.

MANSELL, M. 1978. 'The Last Tasmanian', Racism in Tasmania. Sydney: National Union of Students pamphlet. Also published as MANSELL, M. 1978. Black

Tasmanians Now. Arena 51: 5-8.

MULVANEY, J. 1990 (1961). The Stone Age of Australia. Prehistory and Heritage, The Writings of John Mulvaney, ed. Janine Mummery. Canberra: The Australian National University, 1990: 16-54. First published in 1961. The Prehistoric Society 4: $56-107$

MULVANEY, J. 2001. Peopled Landscapes: From Prehistoric Tasmania to Contemporary Arnhem Land. Histories of Old Ages: Essays in Honour of Rhys Jones, eds. Atholl Anderson, Ian Lilley and Sue O'Connor. Canberra: Pandanus Books: 19-22. 
MURRAY, T. 1992. Tasmania and the Constitution of 'the dawn of humanity. Antiquity 66, 252, Sept: 730-743.

PETCH, A. Tylor and Technology, 'The Other Within' project: http://england.prm.ox.ac.uk/englishness-Tylor-and-technology.html. Accessed 7 July 2015 .

PETROW, S. 1998. The Last man: The Mutilation of William Lanne in 1869 and its Aftermath. Australian Cultural History, 16: 18-44.

PULLEINE, R. 1928. The Tasmanians and Their Stone-Culture. Australasian Association for the Advancement of Science 19: 294-314.

ROE, D. 1981. Amateurs and archaeologists: some early contributions to British Palaeolithic studies. Antiquity and man, essays in honour of Glyn Daniels, J.D. Evans, B. Cunliffe and C. Renfrew (eds). London: Thames \& Hudson: 214-220.

ROTH, H. LING. 1889. A Surviving Tasmanian Aborigine. Nature, 41, 5 December 1889: 105 .

ROTH, H. LING. 1890. The Aborigines of Tasmania. London: Kegan Paul, Trench, Trüber \& Co.

ROTH, H. LING. 1899. The Aborigines of Tasmania. Halifax, England: F. King \& Sons.

RYAN, L. 1985. Extinction Theorists and Tasmanian Aborigines: Apologists for an Extermination Policy. The Future of Former Foragers in Australia and Southern Africa, eds. Carmel Schrire and Robert Gordon. Cambridge, MA: Cultural Survival Inc.: $47-54$.

RYAN, L. 1996. The Aboriginal Tasmanians. Sydney: Allen and Unwin, 1996, 2nd edition.

RYAN, L. 1997. The Struggle for Trukanini 1830-1997. Peter Eldershaw Memorial Lecture Tasmanian Historical Research Association Papers and Proceedings 44, 3: $153-173$

RYAN, L. 2012. Tasmanian Aborigines: A History Since 1803. Sydney: Allen and Unwin.

SACKETT, J. 2014. Boucher de Perthes and the Discovery of Human Antiquity. Bulletin of the History of Archaeology, 24, 2: 1-11, DOI: http://dx.doi.org/10.5334/bha.242

SMITH. N. 1976. Walker, James Backhouse (1841-1899). Australian Dictionary of Biography, National Centre of Biography, Australian National University, http://adb.anu.edu.au/biography/walker-james-backhouse-4786/text7969, published first in hardcopy 1976, accessed online 26 February 2016.

SOLLAS. WJ. 1911. Ancient Hunters and Their Modern Representatives. London, Macmillan. 
TAYLOR, R. 2008. The Polemics of Making Fire: the historical evidence revisited. Aboriginal History, 32, 2008: 1-26.

TAYLOR, R. 2012. The National Confessional. Meanjin Quarterly, 3: 22-36.

TAYLOR, R. 2013. Genocide, Extinction and Aboriginal Self-determination in Tasmanian Historiography. History Compass. 11, 6: 405-419.

TAYLOR, R with M. Jones and G. McCarthy. 2013. See above note on archives.

$$
==
$$

TAYLOR, R. 2014. Australian Archaeology and Aboriginal Protest: how politics and poetry of Rhys Jones' Tasmanian work changed Australian historiography.

Australian Historical Studies 45, 2: 331-349.

TINDALE, N. B. 1937-41. Relationship of the Extinct Kangaroo Island Culture with Cultures of Australia Tasmania and Malaya', Records of the South Australian Museum, VI: 39-59.

TYLOR, E. B. 1871. Primitive Culture. London: John Murray.

TYLOR, E. B. 1890. Preface. Roth, H. Ling, The Aborigines of Tasmania. London: Kegan Paul, Trench, Trüber \& Co: v-viii.

TYLOR, E. B. 1894. On the Tasmanians as Representatives of Palaeolithic Man. Journal of the Royal Anthropological Institute of Britain and Ireland 23: 141-152.

TYLOR, E. B. 1895. On the Occurrence of Ground Stone Implements of Australian Type in Tasmania, Journal of the Royal Anthropological Institute of Britain and Ireland, 24: 335-340.

TYLOR, E. B. 1898. On the Survival of Palaeolithic Conditions in Tasmania and Australia. Journal of the Royal Anthropological Institute of Britain and Ireland, 23: 141-152.

TYLOR, E. B. 1899. Preface. Roth, H. Ling, The Aborigines of Tasmania. Halifax, England: F. King \& Sons: vii-ix.

TYLOR, E. B. 1900. On Stone Implements from Tasmania: Extracts from a Letter by J. Paxton Moir. The Journal of the Royal Anthropological Institute of Great Britain and Ireland, 31: 257-259.

TYLOR, E. B. 1900. On the Stone Age in Tasmania, as Related to the History of Civilisation. Journal of the Royal Anthropological Institute, 30: 33-34.

TYLOR, E. B. 1964. Researches into the Early History of Mankind, ed. Paul Bohannan. Chicago and London: University of Chicago Press. (Republished from the 3rd edition, 1878).

TYLOR, E. B. 1994. The Collected Works of Edward Burnett Tylor with a new introduction by George Stocking. London: Routledge \& Thoemmes.

WALKER, G. W. and Walker, J. B. 1897. Notes on the aborigines of Tasmania, extracted from the manuscript journals of George Washington Walker, with an introduction by Walker, James B. Papers \& Proceedings of the Royal Society of 
Tasmania: 145-175. University of Tasmania ePrints:

http://eprints.utas.edu.au/16183/. Accessed 10 July 2015.

WALKER, BACKHOUSE J. 1900. The Tasmanian Aborigines. Hobart: John Vail Government Printer.

WHITE, J. P. with O'Connell, J. F. 1982. A Prehistory of Australia, New Guinea and Sahul. Sydney: Sydney Academic Press.

WINDSCHUTTLE, K. 2002. The Fabrication of Aboriginal History, Volume One, Van Diemen's Land 1803-1847. Sydney: Macleay Press.

WOOD JONES, F. 1935. Tasmania's Vanished Race. Sydney [?]: Australian Broadcasting Commission.

${ }^{1}$ Moir to Tylor, 23 January 1899, WP, MC, PRM, ff. 36-36v: Image 9,

WESTo0018, Stories in Stone:

http://www.westlakehistory.info/viewer/WEST/item/WESTooo18/9. Accessed 10 July 2015.

2 Tylor, 'Growth and Spread of Culture', TP, MC, PRM.

3 Roth to Walker, 18 October 1891, W9C19_1, UTAS.

4 Petch, Alison: Tylor and Technology, 'The Other Within' project:

http://england.prm.ox.ac.uk/englishness-Tylor-and-technology.html. Accessed 7 July 2015.

5 WL Williamson to EB Tylor from, 6 August 1893 to 16 July 1897, WP, PRM; WL Williamson to EB Tylor, 16 October 1897 and FF Tuckett to EB Tylor 13 February 1895, Tylor Papers, Correspondence S-Y and Miscellaneous, PRM.

${ }^{6}$ These holdings were confirmed by correspondence and archival research I carried out in England from 2008-2009. I am grateful for the support of those institutions in making accessible information from their catalogues and archives.

7 Wilkinson donated more than 50 implements to the British Museum in 1901. Wilkinson to Read, 18 April 1901 DPE, BM; Read to Wilkinson, 30 May 1901, DPE, Outletters 1901, BM.

${ }^{8}$ Moir to Walker, 11 January 1898 w9_c4_1(47)(1), UTAS. Moir explains to Walker that he has written to Johnston and Morton as well.

9 Moir to Walker, 11 January 1898 w9_c4_1(47)(1), UTAS. Moir explains to Walker that he has written to Johnston and Morton as well.

${ }^{10}$ Moir to Walker, 11 January 1898, w9_c4_1(28)(1), UTAS. 
${ }^{11}$ Moir to Tylor, 23 January 1899, WP, MC, PRM, ff. 36-36v. Image 9, WESTooo18: Stories in Stone:

http://www.westlakehistory.info/viewer/WEST/item/WESTooo18/9.

${ }^{12}$ Moir to Tylor, 12 May 1905, WP, MC, PRM, f79v. Image 38, WESTooo19:

Stories in Stone:

http://www.westlakehistory.info/viewer/WEST/item/WESTooo19/38. Accessed 10 July 2015.

13 Moir to Tylor, 21 March 1899, WP, MC, PRM, f. 45; Image 22, WESTooo18: Stories in Stone:

http://www.westlakehistory.info/viewer/WEST/item/WESToo018/22. Accessed 10 July 2015

${ }^{14}$ Moir to Tylor, 26 November 1900, WP, MC, PRM, f. 66v; Image 14, WESTooo19, Stories in Stone:

http://www.westlakehistory.info/viewer/WEST/item/WESTooo19/14. Accessed 10 July 2015.

15 Moir to Tylor, 27 October 1900, WP, MC, PRM, ff. 58, 62; Image 5, WESTo0019: Stories in Stone:

http://www.westlakehistory.info/viewer/WEST/item/WESTooo19/5 and Image 9, WESTo001 www.westlakehistory.info/viewer/WEST/item/WESToo019/9; Moir to Tylor, 26 November 1900, WP, MC, PRM, f. 67; Image 14, WESTooo19, Stories in Stone: $\underline{\text { http://www.westlakehistory.info/viewer/WEST/item/WESTooo19/14. }}$. Accessed 10 July 2015.

${ }^{16}$ Moir to Tylor, 23 January 1899, WP, MC, PRM, ff. 36-36v. Image 9, WESTooo18: Stories in Stone:

http://www.westlakehistory.info/viewer/WEST/item/WESTooo18/9 and Image 10, WESToo018: Stories in Stone

http://www.westlakehistory.info/viewer/WEST/item/WESTooo18/10. Accessed 10 July 2015

17 Walker to Roth, 16 May 1898, XX JB W, MM.

${ }_{18}$ Moir to Tylor, 14 May 1905, WP, MC, PRM, f. 81v; Image 42, WESTooo19: Stories in Stone:

http://www.westlakehistory.info/viewer/WEST/item/WESTooo19/42. Accessed 10 July 2015.

19 Roth to Tylor, 13 February 1899, WP, MC, PRM, f. 41; Image 18, WESTooo18: Stories in Stone: 
http://www.westlakehistory.info/viewer/WEST/item/WESTooo18/18. Accessed 10 July 2015.

${ }^{20}$ Tylor to Roth, 26 February 1899, 27 February 1899, 1 March 1899, XVI 'Various MSS', MM.

${ }^{21}$ Roth to Walker, 30 May 1899, W9C19_32, UTAS.

${ }^{22}$ Moir to Tylor, 12 May 1905, WP, MC, PRM, f. 8ov. Image 40, WESTooo19:

Stories in Stone:

http://www.westlakehistory.info/viewer/WEST/item/WESTooo19/40. Accessed 10 July 2015.

${ }_{23}$ Pitt Rivers to Tylor, 7 August 1898, TP, MC, PRM.

${ }^{24}$ Stocking writes that Tylor's last book was based on the Gifford Lectures he presented in 1889 and 1890 and was to be published in 1907: Tylor 1994: xxiii-xxiv) Stocking refers to printed galleys of some of the book's chapters. I have only seen rough drafts in boxes 5 and $10 \mathrm{TP}, \mathrm{MC}$, PRM. According to a letter to Moir it was to be Growth and Spread of Culture; draft letter Tylor to Moir 25 July 1905, WP, MC, PRM, f. 83v; Image 3, WESTooo20: Stories in Stone:

http://www.westlakehistory.info/viewer/WEST/item/WESTooo20/3. Accessed 10 July 2015.

${ }_{25}$ Tylor, 'Growth and Spread of Culture', TP, MC, PRM.

${ }^{26}$ St George Gray to Read, 29 April 1905, DPE, BM.

${ }^{27}$ Roth to Walker, 18 October 1891,W9C19_1, UTAS.

${ }_{28}$ Walker to Roth, 20 December 1891, XX JBW, MM.

${ }_{29}$ Walker to Roth. 12 March 1893, 30 September 1893, XX JBW, MM.

${ }^{30}$ XIII Jas. B. Walker, MM.

${ }^{31}$ Roth to Walker, 13 April 1898, W9C19_27 UTAS; Felton, p. 24, Maedougall, p. 51.

${ }^{2}$ Walker to Roth, 15 June 1895 , XX JBW, MM.

33 JB Walker's Remarks on Bonwick's Daily Life of the Tasmanians. Notes respecting writers on the Aborigines of Tasmania, XVII 'Various MSS', MM.

34 Walker to Roth, 30 January 1897, 24 April 1897, 3 October 1897, 20 May 1898, XX JBW, MM.

35 Roth to Walker, 15 August 1897, W9C19_18, UTAS.

${ }^{36}$ Walker to Roth, 20 May 1898, XX JBW, MM. 
37 Walker to Roth, 24 April 1897, 17 October 1897, 1 November 1897, 26 December 1897, XX JBW, MM; Quaker Life in Tasmania, Quaker Biographies, Francis Cotton: http://www.utas.edu.au/library/exhibitions/quaker/quaker biographies/quaker bi og f cotton.html. Accessed 5 August 2015.

$3^{8}$ Walker to Roth, 20 May 1898, XX JBW, MM.

39 Walker to Roth, 24 April 1897, XX JBW, MM.

${ }^{40}$ Roth to Walker, 4 August 1898, W9C19_29, UTAS; Walker to Roth, 20 May 1898, 11 June 1898, XX JBW, MM.

${ }^{41}$ Walker to Roth 15 June 1895, XX JBW, MM.; Roth to Walker, 3 August 1898, W9C19_6, UTAS.

42 Walker to Roth, 3 October 1897, 20 May 1898, XX JBW, MM.

43 Roth to Walker, 13 April 1898, W9C19_27, UTAS.

44 Walker to Roth, 3 October 1897, 12 December 1897, XX, MM.; Roth to Walker, 23 September 1898, W9C19_31, UTAS.

45 Beattie to Roth, 22 September 1893, XIX JWB, MM.

${ }^{46}$ Walker to Roth, 30 January 1897, XX JBW, MM.

47 Roth to Walker, 6 May 1897, W9C19_15, UTAS.

48 Walker to Roth, 3 October 1897, XX JB,W, MM.

49 Walker to Roth, 10 June 1896, 20 May 1898 and 16 May 1899, XX JBW, MM. Rayner to Walker (copied by Walker for Roth) 20 April 1898, XXVV, MM.

$5^{\circ}$ Walker to Roth, 24 April 1897, XX JBW, MM; Walker and Walker, 'Notes on the aborigines of Tasmania'.

${ }^{51}$ Walker to Roth, 21 March 1894, 30 Jan 1897, 24 April 1897, 17 October 1897, 20 November 1897, 9 October 1898, 16 May 1899 XX JBW, MM.

$5^{2}$ Beattie to Roth, 12 March 1897, XIX JWB, MM., Walker to Roth, 14 and 27 March 1897, XX, MM., Roth to Walker, 6 May 1897, W9C19_15, UTAS.

53 Walker to Roth. 12 March 1893, 30 September 1893, XX JBW, MM.

54 Beattie to Roth, 23 September 1893, XIX JWB, MM.

55 Beattie to Roth, 3 March 1894, XIX JWB, MM.

${ }^{56}$ Beattie to Roth, 12 October 1894, XIX JWB, MM.

57 Roth to Walker, 3 August 1895, W9/C1/9_14, UTAS.

${ }^{58}$ Beattie to Roth, 2 November 1896, XIX JWB, MM. 
59 Holden to Beattie, 3 January 1897, XVI 'Various MSS' (mistakenly dated as 1896 by Holden, but sent promptly after receipt by Beattie to Roth: 11 January 1897, XIX JWB, MM)

${ }^{60}$ Geeves to Beattie, 21 October 1896, forwarded to Roth, XIX JWB, MM.

${ }^{61}$ Geeves to Beattie, 21 October 1896, forwarded to Roth, XIX JWB, MM.

${ }^{62}$ Beattie to Roth, 10 July 1897 (see also 27 February 1897), XIX JWB, MM.

${ }^{63}$ Beattie to Roth, 4 December 1897, XIX JWB, MM.

${ }^{64}$ Beattie to Roth, 27 February 1897, XIX JWB, MM., Walker to Roth, 12 December 1897, XX, MM., Roth to Walker, 14 April? 1898, W9C19_25, UTAS.

65 Roth, The Tasmanian Aborigines, 1899, p. 1xxxiv.

${ }^{66}$ Roth to Walker, 14 April? 1898, W9C19_25, UTAS.

67 Walker to Roth, 14 March 1897, XX JBW, MM.

68 Walker to Roth, 30 September 1893, XX, MM; Roth to Walker, 3 August 1895, W9C19_6, UTAS; Walker to Roth, 24 September 1899, XX JBW, MM.

68 Tylor to Roth, 14 February 1899, XVI 'Various MSS', MM.

69 Walker to Roth, 14 August 1899, XX, MM.

${ }^{70}$ Walker to Roth, 14 August 1899, XX JBW, MM.

${ }^{71}$ For a more extended version of some of the ideas set out in this epilogue see Taylor 2014 .

${ }^{2}$ Ronin Films, 'The Last Tasmanian Study Guide': www.roninfilms.com.au/get/files/987.pdf. Accessed 24 July 2015.

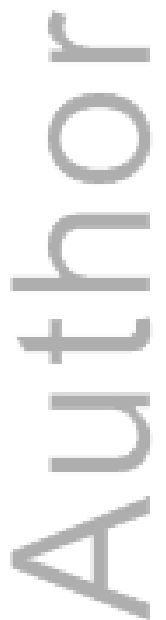




\section{University Library}

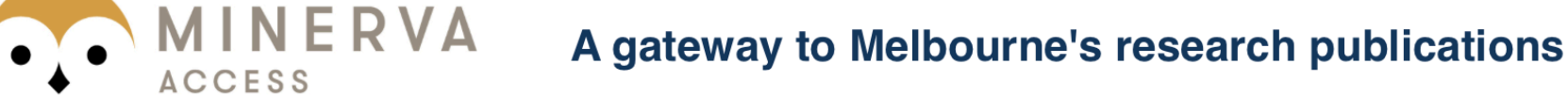

Minerva Access is the Institutional Repository of The University of Melbourne

Author/s:

Taylor, R

Title:

The First Stone and the Last Tasmanian: The Colonial Correspondence of Edward Burnett Tylor and Henry Ling Roth

\section{Date:}

2016-11-01

\section{Citation:}

Taylor, R. (2016). The First Stone and the Last Tasmanian: The Colonial Correspondence of Edward Burnett Tylor and Henry Ling Roth. OCEANIA, 86 (3), pp.320-343. https:// doi.org/10.1002/ocea.5145.

Persistent Link:

http://hdl.handle.net/11343/291892 